\title{
RESEARCH
}

Open Access

\section{Understanding equity of institutional delivery in public health centre by level of care in India: an assessment using benefit incidence analysis}

\author{
Sanjay K. Mohanty ${ }^{1 *}$ D, Radhe Shyam Mishra², Suyash Mishra² and Soumendu Sen²
}

\begin{abstract}
Background: The National Health Mission (NHM), the largest ever publicly funded health programme worldwide, used over half of the national health budget in India and primarily aimed to improve maternal and child health in the country. Though large scale public health investment has improved the health care utilization and health outcomes across states and socio-economic groups in India, little is known on the equity concern of NHM. In this context, this paper examines the utilization pattern and net benefit of public subsidy for institutional delivery by the level of care in India.
\end{abstract}

Methods: Data from the most recent round of the National Family Health Survey (NFHS 4), conducted during 2015-16, was used in the study. A total of 148,645 last birth delivered in a health centre during the 5 years preceding the survey were used for the analyses. Out-of-pocket (OOP) payment on delivery care was taken as the dependent variable and was analysed by primary care and secondary level of care. Benefits Incidence Analysis (BIA), descriptive statistics, concentration index $(\mathrm{Cl})$, and concentration curve $(\mathrm{CC})$ were used to do the analysis.

Results: Institutional delivery from the public health centres in India is pro-poor and has a strong economic gradient. However, about 28\% mothers from richest wealth quintile did not pay for delivery in public health centres compared to $16 \%$ among the poorest wealth quintile. Benefit incidence analyses suggests a pro-poor distribution of institutional delivery both at primary and secondary level of care. In 2015-16, at the primary level, about 32.29\% of subsidies were used by the poorest, $27.22 \%$ by poorer, $20.39 \%$ by middle, $13.36 \%$ by richer and $6.73 \%$ by the richest wealth quintile. The pattern at the secondary level was similar, though the magnitude was lower. The concentration index of institutional delivery in public health centres was $-0.161[95 \% \mathrm{Cl},-0.158,-0.165]$ compared to 0.296 [95\% Cl, 0.289, 0.303] from private health centres.

Conclusion: Provision and use of public subsidy for institutional delivery in public health centres is pro-poor in India. Improving the quality of service in primary health centres is recommended to increase utilisation and reduce OOP payment for health care in India.

Keywords: Delivery care, Benefit incidence, Equity, National Health Mission, India

\footnotetext{
*Correspondence: sanjayiips@yahoo.co.in

'Department of Fertility Studies, International Institute for Population Sciences, Mumbai, India

Full list of author information is available at the end of the article
}

C C The Author(s). 2020 Open Access This article is licensed under a Creative Commons Attribution 4.0 International License, which permits use, sharing, adaptation, distribution and reproduction in any medium or format, as long as you give appropriate credit to the original author(s) and the source, provide a link to the Creative Commons licence, and indicate if changes were made. The images or other third party material in this article are included in the article's Creative Commons licence, unless indicated otherwise in a credit line to the material. If material is not included in the article's Creative Commons licence and your intended use is not permitted by statutory regulation or exceeds the permitted use, you will need to obtain permission directly from the copyright holder. To view a copy of this licence, visit http://creativecommons.org/licenses/by/4.0/ The Creative Commons Public Domain Dedication waiver (http://creativecommons.org/publicdomain/zero/1.0/) applies to the data made available in this article, unless otherwise stated in a credit line to the data. 


\section{Introduction}

Increasing health spending and rising health inequality are concomitant across geographies and socio-economic groups [1-4]. Rising health spending is associated with increased public investment in health and declining outof-pocket (OOP) payments [5, 6]. Despite the increased public investment, catastrophic health spending (CHS) and impoverishment resulting from OOP payment have been increasing in many developing countries [7-9]. CHS, and impoverishment, due to health spending vary across countries and depend on income level, public policies, coverage of health insurance schemes, type of provider, payment methods, disease burden and demographics [10-12]. Globally about 1.3 billion people do not have access to effective and affordable health care. Of those who do have access, about 170 million are forced to spend more than $40 \%$ of their household income on medical treatment. Over 100 million people are pushed into extreme poverty due to health spending annually [13].

Equity and efficiency are two pillars of public health investment worldwide. Goal 4 and 5 of the Millennium Development Goals (MDGs) and goal 3 and 10 of the Sustainable Development Goals (SDGs) outlined the specific goals to reduce inequality in access and utilization to quality health services [14, 15]. Goal 3.7 aimed to achieve universal access to sexual and reproductive health-care services, while Goal 3.8 aim to achieve universal health coverage, financial risk protection, and access to quality health services by 2030 . The progress in access to these services, measured by the universal health index (UHI) of service coverage based on reproductive health, nutrition, new-born and child health, infectious diseases, non-communicable diseases and service capacity and access among the general and most advantages population is slow and uneven across and within countries. Financial protection, as measured by catastrophic health spending, a key impediment in access to health services, has increased from $9.7 \%$ in 2000 to $11.7 \%$ by 2010 [7] and then, also increased in impoverishment due to the medical expenditure [16].

Many welfare governments have made large-scale investments to increase the access and utilisation of health care services. Periodic evaluation suggests a mixed impact of public health investment on health care utilization and health outcomes [17-20]. Public subsidy for health care increases utilization and reduced inequality in access to it $[21,22]$. The equity impact of the public subsidy varies by the level of care (primary health centre and hospital) and the type of services (inpatient and outpatient) $[17,20,23]$. In most of the African countries, the distribution of public subsidy benefits the rich more the than poor (it is pro-rich) irrespective of the level of care $[21,24,25]$, while in Asia, varying pattern are observed. In India, Indonesia and Vietnam, the distribution of public subsidy is pro-poor at the level of primary health centre (PHC) and pro-rich at hospitals while in China, Pakistan, Nepal, and Bangladesh it is pro-rich at all levels [20, 26, 27]. In Thailand, Malaysia and Sri Lanka, pro-poor pattern is observed at all level of care $[26,28]$. Public subsidy benefits rich more due to its higher utilization by them and due to impediments faced by the poor in availing the services [23, 26, 29].

Studies have used various approaches to understand the impact of public health investment (benefit-incidence analysis, individual preference, concentration curve, and concentration index). Among these, benefit incidence analyses (BIA) is being increasingly used in health economics literature [23, 26-28, 30-33]. Benefit incidence analysis is a tool to access whether the subsidies are helping the poorer section, or the better-off section of the society. It also involves the estimating of the monetary value of the services and their distribution among the population [24]. The analysis helps to capture the effectiveness of the governments in distribution of limited resources to meet the needs of the poor [30].

Over a decade ago, the state of maternal and child health was poor in the country. In 2002-03, the maternal mortality ratio was 286 per 100,000 live births, and the under-five mortality was 74 per 1000 live births [34, 35]. Over half of the mothers did not delivered at a health centre. The prevalence of institutional delivery among women from the poorest wealth quintile was $12.8 \%$ compared to $83.6 \%$ among those from the richest quintile in 2005 [34]. Inequality was large in the health care utilization [4, 36-38] and the public health subsidies were pro-rich in nature [20]. As a policy response, the Government of India in 2005 revamped the health programme and launched the National Health Mission (NHM), the largest ever health program worldwide. The main objective of the NHM was to improve maternal and child health care in the poorer regions of the country and among the poor and vulnerable sections of the population. The NHM had an estimated annual budget of over ₹26,691 scores in 2017-18, accounting, for more than half of the health budget of the union government [39]. The large-scale public health investments have reduced maternal and child mortality in the country. Deliveries in public health centres has increased from $18 \%$ in $2005-06$ to $52.1 \%$ by $2015-16$ [34, 40]. Studies suggest that inequality in health care services has widened across state, rural, and urban areas and wealth quintile $[41,42]$. Besides, India, with an UHI service coverage value of 55 is far below the global average of 66 [13]. The slow progress in UHI is associated with high OOP and catastrophic health spending (CHS) [43-46]. About $71 \%$ of health spending was met by households in 2004 and $69.1 \%$ in 2014 was met by household themselves 
$[47,48]$. OOP is larger in poorer states and among poorer people of poorer states [49]. The catastrophic health spending has shown an increasing pattern, increased from $11.1 \%$ in $1995-96$ to $24.9 \%$ by 2014 [8]. About $3.5 \%$ population were impoverished due to medical spending, and about 50.6 million were poor due to medical spending [50].

A number of studies in India have used the BIA approach to examine the benefits of public subsidy on inpatient care, out-patient care, and delivery care. The distribution of public subsidies in Karnataka was six times higher for the richest $20 \%$ of the population compared to the poorest 20\% [51]. In Northeast India, the benefits of inpatient care were pro-poor in urban and pro rich in rural areas [52]. A recent study found a prorich distribution of public subsidy for inpatient care of non-communicable diseases (NCDs) among the elderly [53]. In West Bengal, the benefit of public subsidy was highest for the lower-middle income group in rural areas and for the upper-middle income group in urban areas [23]. During 2004-14, changing pattern of public subsidy for inpatient care was found in Tamil-Nadu, Rajasthan and West Bengal [32]. A recent study suggests that inpatient and delivery services at public health facilities in India are pro-poor [30].

In developing countries, public investment in health has remained low over time and the effectiveness of public spending on healthcare services continue to be an elusive empirical issue. Increasing public health expenditure on health care services does not automatically benefit all groups of the population if the distribution of resources is not equitable [54]. While the average utilization of services may increase, it may not necessarily benefit the poor and the marginalized [55]. Therefore, it is important to empirically assess whether public spending in India truly benefits the poorer section of the population. The national average of the utilisation of delivery care services in public health centres conceals large variations across states and economic groups. Though there has been an increase in the utilization of maternal services in public health centres, little is known as to who is benefiting and it is unclear whether the benefits are largely pro-poor or pro-rich. With this background, we used the BIA and concentration index to examines the equity in the distribution of public subsidy among the mothers using public health centres for institutional delivery.

\section{Data and methods}

Unit data from the most recent round of the National Family Health Survey (NFHS-4) conducted during 2015-16 was used for the analysis. NFHS 4 is the fourth in the series of Demographic Health Survey (DHS) in India that aimed to provide reliable estimates of the utilization of maternal and child health services, contraception, nutrition etc. along with the socio-economic and demographic condition of the households. The NFHS 4 survey used three schedules namely, the household, the women, and the men schedules to collect demographic, health, social and economic information of the household. The household schedule collects information on age, education of members, household amenities, and assets in the household. The women schedule was canvassed to women aged 15-45 years to collect information on such things as fertility, contraception, birth history, ante-natal, natal and post-natal care from sampled households. While information on maternal care services was collected for all the births during the 3 years preceding the survey, information on OOP expenditure on delivery was collected for the last birth in a reference of a five-year periods.

NFHS 4 used multistage stratified sampling using the Census of India, 2011 sampling frame for the selection of the Primary Sampling Units (PSUs). Villages in rural areas and Census Enumeration Blocks (CEBs) in urban areas were used as PSUs. The PSUs were arranged according to female literacy rate and proportion of SC/ST population and were selected using Probability Proportional to Size (PPS) sampling. A complete house listing operation was carried out in each PSU prior to the survey and an average of 22 households were chosen from each selected PSU. The survey successfully interviewed 601,509 households and 699,686 ever married women in the age group 15-49, and 112,122 men in the age group of 15-54 across all states and union territories of India. The NFHS- 4 for the first time, included a set of policy-relevant questions on OOP payment on delivery care (defined as the expenditure net of reimbursement) for the last birth delivered at a health centre and reimbursement under the Janani Suraksha Yojana (JSY). Findings of the survey, along with the sampling design, methodology, and results are available in the national report [40].

Unit data from the kids file, which provides details of births to mothers during the 5 years preceding the survey, was also used. A total of 259,627 births were reported of which 190,898 were last births, and 148, 645 were conducted in the health centres (institutional delivery). The unit data was cleaned for factual errors on OOP payment before the analysis. The details of and procedures used for data cleaning are available elsewhere [44].

\section{Statistical analysis}

Descriptive statistics, Benefit Incidence Analysis (BIA), and Concentration Index (CI), and Concentration Curve (CC) were used in the analysis. 


\section{Variables}

A set of variables including institutional delivery, type of health centre (private/public), level of care at the public health centre (sub-centre [SC], primary health centre $[\mathrm{PHC}]$, urban family welfare centre [UFWC], urban primary health centre [UPHC]/government, municipal, rural hospital), OOP payment, place of residence (rural/ urban), type of states (low performing / high performing), educational attainment and wealth quintile are used in the analyses. Institutional delivery is defined as the birth of a child at a health centre, classified as either public (government-funded) or private. Care received from Sub-centre, PHC, UHC, UFWC, and UPHC was classified as primary care, while that from government/ municipal and rural hospitals was classified as secondary care to allow for a sufficient sample size by each characteristic. The OOP payment, defined as expenditure on delivery care in a health centre without reimbursement was used as the dependent variable. In NFHS 4, the following question on OOP was asked to the mother to estimate there OOP on their last birth "How much in total did it cost you out of your pocket for this delivery?". The OOP was recorded for a five-year period preceding the survey. We have adjusted the OOP to a constant price using a state wise monthly consumer price specific to rural/urban areas. The estimates were provided at 2016 prices. This procedure was used in a recent paper and has been adopted in to derive comparable OOP [44].

The analyses was carried out by characteristics such as rural and urban areas, education (mother's) of less than five and more than 5 years and low and high performing states (based on the rate of institutional delivery). The economic gradient was measured using wealth index, a composite index based on household assets, durable goods, household amenities etc. In the absence of income or consumption expenditure in the DHS survey, the wealth index is used to measure economic differential in health and health care utilization [40]. In NFHS 4, a set of 43 variables used to derive the wealth index using the principal component analyses (PCA). The wealth index is further classified into five quintile and termed as poorest, poorer, middle, richer and richest. The last birth to a mother, during the 5 years preceding the survey was the unit of analyses.

\section{Benefit incidence analysis}

To determine the distribution of benefits received by various socio-economic groups using public health services for delivery care, Benefit Incidence Analysis has been used. One of the difficulties with benefit incidence analyses is obtaining the cost of services. In the absence of the cost of services, the modal value of OOP payment for delivery has been used in the literature [53]. For our study we used the median value rather than the mean and mode of OOP as a proxy for the cost of services. Like any expenditure data, we found the distribution of OOP to be skewed which made mean unsuitable. Besides, a significant proportion of the mothers had not paid for the services at public/accredited private health centres as they had likely received free services under the Janani Suraksha Yojana Scheme (a demand-side financing scheme for poor mothers in India), making the modal value zero for delivery cost.

The following steps have been used in estimating the benefit-incidence of institutional delivery.

i. Computing wealth quintile (population ranked by wealth) as a measure of socio-economic status.

ii. Estimating the utilization rate for delivery care in public health centres for each quintile.

iii. Estimating net subsidy at public health centres for each quintile (obtained by deducting the median OOP payment on delivery care in public health centres from median OOP payment in private health centres)

iv. Estimating individual subsidy for each quintile by multiplying the net subsidy with the utilization rate.

v. Calculating Benefit Incidence for each quintile by taking percentage share of the individual subsidy.

We estimated the benefit incidence of a particular group j utilizing service $\mathrm{i}$ (institutional delivery) in public health centres. The OOP payment in private health centres was taken to be synonymous to the cost of services. Most health insurances in India do not provide any coverage/reimbursement for the maternal care; and so OOP was taken to be equivalent to household expenditure. In case, no charge was levied, the OOP payment was considered zero.

Mathematically, the benefit incidence is defined as follows:

$$
\mu_{j}=\sum \alpha_{i j} \frac{\beta_{i}}{\alpha_{i}}=\sum \gamma_{i j} \beta_{i}
$$

Where,

$$
\begin{aligned}
& \mu_{j}=\text { benefit of public subsidy enjoyed by group } i \\
& \alpha_{i j}=\text { utilization of delivery care }(i) \text { by group } j \\
& \alpha_{i}=\text { utilization of delivery care }(i) \text { by all groups } \\
& \beta_{i}=\text { government net expenditure on delivery care }(i) \\
& \gamma_{i j}=\text { group } j \text { share of utilization of delivery care }(i)
\end{aligned}
$$

OOP payment and cost of service on institutional delivery We computed the OOP payment by wealth quintile for mothers delivering at public health centres. NFHS-4 did 
not include any information on the actual cost of delivery care at the public health centre. Hence in line with previous literature, we have used the OOP payment for delivery care in private health centres as the proxy for the actual cost of delivery care in public health centres $[23,32]$.

\section{Concentration index $(\mathrm{Cl})$ and concentration curve (CC)}

To examine the economic inequality in the utilization of delivery care services in public/private health centre, we used CC and CI. CC and CI are commonly used by researchers to measure health inequality $[56,57]$. CC plots the cumulative proportion of the population (ranked by wealth) against the cumulative proportions of the population utilizing delivery care services in public/private health centres. If CC overlaps with the line of equality, then the extent of utilization of services from public/private health centres is evenly distributed across the wealth group. However, if $\mathrm{CC}$ lies above the line of equality, it implies a pro-poor concentration of utilization of delivery care services while if $\mathrm{CC}$ lies below the line of equality, it implies a pro-rich concentration in the utilization of delivery care services. $\mathrm{CI}$ is defined as twice the area between the $\mathrm{CC}$ and the line of equality. The value of CI ranges from -1 to +1 , with a value of zero suggesting an equal distribution of utilization of services across the wealth group. A negative value signifies a pro-poor distribution of utilization of delivery care services while a positive value signifies a pro-rich distribution [58].

\section{Result}

Figure 1 presents the distribution of institutional delivery by wealth quintile and type of health centres in India. The utilization of institutional delivery in public health centres declines with an increase in the economic wellbeing of the households. On the other hand, the economic gradient in the utilization of institutional delivery in private health centres was strong and positive. For example, among all institutional deliveries in the poorest wealth quintile, $86 \%$ were in public health centre compared to $14 \%$ in the private ones. By contrast, in the richest wealth quintile, about two-third women used private health centre for delivery care. A majority of the women from the poorest, poorer, and middle quintile availed delivery care in public health centres.

Table 1 presents the socio-demographic characteristics of the study population. About 33\% (95\% CI: 32.6-33.4) of the respondents resided in urban areas while $67 \%$ resides in the rural areas (95\% CI: 66.6-67.4). About onequarter of the respondents had an educational level of less than 5 years $(26.9 \%$; $95 \%$ CI: $26.6-27.2)$ while threefourth of them (73.1, 95\% CI: 72.7-73.4) had more than 5 years of education. About $48.8 \%$ (95\% CI: 48.4-49.2) of the respondents resides in low performing states while 51.2\% (95\% CI: 50.8-51.6) resided in the high performing ones. With respect to social group, $29.8 \%$ (95\% CI: 29.5-30.2) of the respondents belonged to schedule caste or schedule tribe, $44.1 \%$ (95\% CI: 43.7-44.5) belongs to other backward class, and $26.1 \%$ belonged to other social groups (95\% CI: 25.7-26.4). About 64.7\% (95\% CI: 64.3-65.1) of the mothers went to public health centres for institutional delivery while, $35.2 \%$ of the respondents used private health centres $(35.3 \%$; $95 \% \mathrm{CI}$ : 34.9-35.7). Among respondents utilizing public health centres, 52.8\% (95\% CI: 52.5-53.2) utilized government/ municipal hospitals, rural hospitals while $11.9 \%$ (95\% CI, 11.6-12.1) utilized Sub-centres, PHC, UHC, others facilities. About 42.5\% (95\% CI, 42.1-42.9) respondents made less than 4 ANC visit while $57.5 \%$ (95\% CI, 57.157.9) respondents made 4 or more ANC visits.

Table 2 presents the percent distribution of women who availed delivery services with and without payment at private and public health centre by wealth quintile in

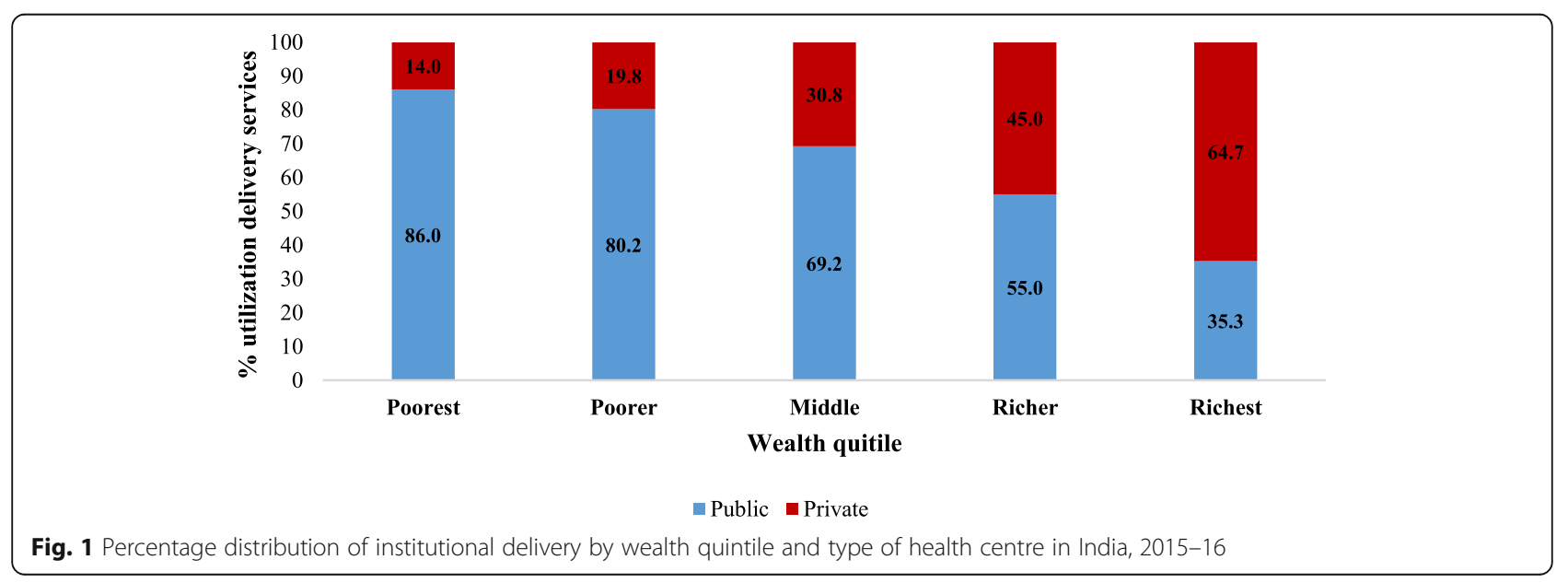


Table 1 Sample profile of the study population based on NFHS-4, 2015-16, India

\begin{tabular}{|c|c|c|}
\hline Variables & Percentage (\%) & 95\% Confidence Interval \\
\hline \multicolumn{3}{|l|}{ Place of residence } \\
\hline Urban & 33.0 & $32.6-33.4$ \\
\hline Rural & 67.0 & $66.6-67.4$ \\
\hline \multicolumn{3}{|l|}{ Educational Level } \\
\hline Less than 5 years & 26.9 & $26.6-27.2$ \\
\hline 5 years and more & 73.1 & $72.7-73.4$ \\
\hline \multicolumn{3}{|l|}{ State type } \\
\hline Low performing states & 48.8 & $48.4-49.2$ \\
\hline High performing states & 51.2 & $50.8-51.6$ \\
\hline \multicolumn{3}{|l|}{ Social Group } \\
\hline Schedule caste / Schedule tribe & 29.8 & $29.5-30.2$ \\
\hline Other backward class & 44.1 & $43.7-44.5$ \\
\hline Others & 26.1 & $25.7-26.4$ \\
\hline \multicolumn{3}{|l|}{ Household size } \\
\hline Up to 5 & 47.5 & $47.1-47.9$ \\
\hline 6 and more & 52.5 & $52.1-52.9$ \\
\hline \multicolumn{3}{|l|}{ Place of Delivery } \\
\hline Public facility & 64.7 & $64.3-65.1$ \\
\hline Private facility & 35.3 & $34.9-35.7$ \\
\hline \multicolumn{3}{|l|}{ Level of care at public health centres } \\
\hline Government/Municipal, Rural Hospital & 52.8 & $52.5-53.2$ \\
\hline Sub-centre, PHC, UHC, others ${ }^{a}$ & 11.9 & $11.6-12.1$ \\
\hline \multicolumn{3}{|l|}{ Number of ANC visits } \\
\hline Less than 4 & 42.5 & $42.1-42.9$ \\
\hline 4 and more & 57.5 & $57.1-57.9$ \\
\hline
\end{tabular}

athers include additional Primary Healthcare Centre (PHC), Urban Health Post (UHP), Urban Family Welfare Centre (UFWC), Public sector health facility

Table 2 Percent distribution of mothers who paid and did not pay for institutional delivery by wealth quintile and type of health centres in India, 2015-16

\begin{tabular}{|c|c|c|c|c|c|c|c|c|c|c|c|c|c|c|c|}
\hline \multirow[t]{2}{*}{$\begin{array}{l}\text { Wealth } \\
\text { Quintile }\end{array}$} & \multicolumn{3}{|c|}{$\begin{array}{l}\text { Sub-centres, PHC, UHC } \\
\& \text { Others }^{\mathrm{a}}\end{array}$} & \multicolumn{3}{|c|}{$\begin{array}{l}\text { Government/Municipal, } \\
\text { Rural Hospital }\end{array}$} & \multicolumn{3}{|c|}{ Any public health facility } & \multicolumn{3}{|c|}{ Private health facility } & \multicolumn{3}{|c|}{ Overall } \\
\hline & $\begin{array}{l}\text { Paid } \\
(\%)\end{array}$ & $\begin{array}{l}\text { Didn't } \\
\text { pay (\%) }\end{array}$ & $\mathbf{N}$ & $\begin{array}{l}\text { Paid } \\
(\%)\end{array}$ & $\begin{array}{l}\text { Didn't } \\
\text { pay (\%) }\end{array}$ & $N$ & $\begin{array}{l}\text { Paid } \\
(\%)\end{array}$ & $\begin{array}{l}\text { Didn't } \\
\text { pay (\%) }\end{array}$ & $\mathrm{N}$ & $\begin{array}{l}\text { Paid } \\
\text { (\%) }\end{array}$ & $\begin{array}{l}\text { Didn't } \\
\text { pay (\%) }\end{array}$ & $\mathrm{N}$ & $\begin{array}{l}\text { Paid } \\
(\%)\end{array}$ & $\begin{array}{l}\text { Didn't } \\
\text { pay (\%) }\end{array}$ & $\mathrm{N}$ \\
\hline Poorest & 79.8 & 20.2 & 5792 & 84.4 & 15.6 & $\begin{array}{l}18, \\
726\end{array}$ & 83.4 & 16.6 & $\begin{array}{l}24, \\
518\end{array}$ & 90.8 & 9.2 & 3223 & 84.4 & 15.6 & $\begin{array}{l}27, \\
741\end{array}$ \\
\hline Poorer & 76.0 & 24.0 & 5731 & 82.1 & 17.9 & $\begin{array}{l}20 \\
904\end{array}$ & 80.9 & 19.1 & $\begin{array}{l}26, \\
635\end{array}$ & 92.6 & 7.4 & 5167 & 83.2 & 16.8 & $\begin{array}{l}31 \\
802\end{array}$ \\
\hline Middle & 75.5 & 24.5 & 4231 & 78.3 & 21.7 & $\begin{array}{l}19, \\
822\end{array}$ & 77.8 & 22.2 & $\begin{array}{l}24 \\
053\end{array}$ & 92.5 & 7.5 & 7838 & 82.3 & 17.7 & $\begin{array}{l}31 \\
891\end{array}$ \\
\hline Richer & 70.8 & 29.2 & 2511 & 76.8 & 23.2 & $\begin{array}{l}16 \\
165\end{array}$ & 75.9 & 24.1 & $\begin{array}{l}18, \\
676\end{array}$ & 91.5 & 8.6 & $\begin{array}{l}11, \\
149\end{array}$ & 82.9 & 17.1 & $\begin{array}{l}29, \\
825\end{array}$ \\
\hline Richest & 70.2 & 29.8 & 1161 & 71.8 & 28.2 & $\begin{array}{l}10 \\
572\end{array}$ & 71.6 & 28.4 & $\begin{array}{l}11 \\
733\end{array}$ & 91.0 & 9.0 & $\begin{array}{l}15 \\
653\end{array}$ & 84.2 & 15.9 & $\begin{array}{l}27, \\
386\end{array}$ \\
\hline Total & 75.9 & 24.1 & $\begin{array}{l}19, \\
426\end{array}$ & 79.5 & 20.5 & $\begin{array}{l}86 \\
189\end{array}$ & 78.9 & 21.1 & $\begin{array}{l}105 \\
615\end{array}$ & 91.6 & 8.5 & $\begin{array}{l}43 \\
030\end{array}$ & 83.3 & 16.7 & $\begin{array}{l}148, \\
645\end{array}$ \\
\hline
\end{tabular}

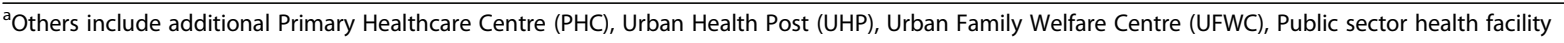


India. About $17 \%$ of the respondents did not pay for delivery care in India, and it varies from $15.6 \%$ in the poorest wealth quintile to $17.7 \%$ in the middle wealth quintile. Among those who availed services in public health centres, the proportion of women who did not pay for delivery care increases by wealth quintile. For example, among respondents who went to primary health centres, $20 \%$ in the poorest wealth quintile did not pay for services compared to $30 \%$ in the richest wealth quintile. Similarly, among those availing services from secondary health centres, about $16 \%$ women in the poorest wealth quintile did not pay for delivery care compared to $28 \%$ in the richest wealth quintile. In case of any public health facility, about $17 \%$ of the women in poorest wealth quintile did not pay for delivery care compared to $28 \%$ in the richest wealth quintile. In the case of private health centres, the proportion of those who did not pay for institutional delivery varied from $7.4 \%$ in the poorer quintile to $9.2 \%$ in the poorest quintile.

Table 3 present the benefit incidence of the public subsidy on delivery care by wealth quintile and level of care in India. The utilization rate in primary health centres varied from $31.9 \%$ among the poorest quintile to $6.8 \%$ in the richest quintile whereas in secondary health centres, it varied from $23.3 \%$ among the poorest quintile to $13.6 \%$ in the richest quintile. In case of any public health centre, it varied from $24.8 \%$ among the poorest quintile to $12.3 \%$ among the richest quintile. By using the overall median OOP payment for service availed in private health centre as the proxy for the cost of services, the public subsidy was found to be pro-poor in each public health facility. During 2015-16, public subsidy in primary health centres was the highest for the poorest quintile (32.29\%) followed by the poorer quintile (27.23\%) while it was lowest for the richest quintile (6.73\%). With regard to secondary health centre, the benefit of public subsidy was maximum for the poorest quintile $(23.63 \%)$ followed by the poorer quintile (22.55\%) while it was the lowest for the richest quintile (13.79\%). Considering the quintile specific median cost of service in private health centre, the pattern of the benefit of public subsidy remained similar for primary health centres while different pattern was observed in case of secondary health centre. For instance, in case of any public health centre, the benefit of public subsidy was highest for the middle quintile (21.93\%) followed by the richer quintile $(21.84 \%)$ while it was the lowest for the poorest quintile (17.42\%) (Additional file 1).

Table 4 presents the results of the benefit incidence of institutional delivery in India by place of residence, low/ high performing states, educational attainment and social group in PHCs, sub-centre, UHCs, and others public health care faculties. The distribution of public subsidy for each of the selected variables was pro-poor in nature.
In urban area, the highest share of the benefit was received by women belonging to the poorest quintile (34.39\%), followed by those from the poorer quintile (24.93\%) while it was the lowest among women from the richest quintile (9.59\%). In the case of rural areas, the share of benefit received was highest for women belonging to poorest quintile (27.34\%) followed by women from the poorer quintile (24.73\%) while it was the lowest among women from the richest quintile $(9.76 \%)$. The utilization rate in public health facilities of low performing states (LPS) varied from $28.4 \%$ among women from the poorest quintile to $8.1 \%$ among women from the richest wealth quintile. On the other hand, it varied from $34.4 \%$ among those from the poorest quintile to $6.5 \%$ among women from the richest quintile in the high performing states (HPS). The share of public subsidy in LPS was highest among the women belonging to the poorest quintile $(28.67 \%)$ followed by those form the poorer quintile (26.35\%), while it was the lowest among the richest quintile (7.99\%). In the case of HPS, the share of the benefit was the highest among the poorest quintile (34.44\%) followed by poorer $(27.02 \%)$, while it was the minimum among the richest quintile (6.5\%). The utilization rate of public health centres among women with less than 5 years of schooling varied from $25.4 \%$ among those from poorest quintile to $11.7 \%$ among those from the richest quintile while, it varied from $34.4 \%$ among those from the poorest quintile to $6.8 \%$ among those from the richest quintile. The share of public subsidy for women with less than 5 years of schooling was highest for those belonging to the poorest quintile $(25.79 \%)$ followed by the poorer quintile (23.11\%), while it was lowest for among women from the richest quintile (11.89\%). Among mothers having more than 5 years of education, the share of public subsidy was the highest among the poorest quintile (34.64\%), followed by the poorer quintile (26.98\%) while it was the lowest for among the richest quintile (6.80\%). The utilization pattern and net benefit from public subsidy across social groups by wealth quintile followed a similar pattern; with a higher utilization and greater benefit from seen among mothers belonging to the poorest wealth quintile compared to those from the richest wealth quintile. For example, among mothers belonging to SC/ST, $27.8 \%$ of those from the poorest quintile used public services in primary health centres compared to $8.2 \%$ of those from the richest quintile. The share of the benefit of public subsidy was also the highest among women from the poorest quintile $(28.10 \%)$ followed by poorer quintile $(25.91 \%)$ while it was the lowest among those from the richest quintile (8.05\%).

Further, the benefit incidence was computed for women using government/municipal hospitals, rural 
Table 3 Utilization rate, out-of-pocket payment (OOP in US\$), and benefit incidence on institutional delivery by wealth quintile and level of care in India, 2015-16

\begin{tabular}{|c|c|c|c|c|c|c|c|c|c|}
\hline $\begin{array}{l}\text { Type of public } \\
\text { health centre }\end{array}$ & Quintile & $\begin{array}{l}\text { Number } \\
\text { people } \\
\text { utilizing public } \\
\text { health service } \\
\text { (1) }\end{array}$ & $\begin{array}{l}\text { Utilization } \\
\text { Rate (2) }\end{array}$ & $\begin{array}{l}\text { Median OOP } \\
\text { in public } \\
\text { health service } \\
\text { in US\$ (3) }\end{array}$ & $\begin{array}{l}\text { Median cost of } \\
\text { service in private } \\
\text { health centre in } \\
\text { US\$ (4) }\end{array}$ & $\begin{array}{l}\text { Net subsidy at } \\
\text { public health } \\
\text { centre in US\$ } \\
(5=4-3)\end{array}$ & $\begin{array}{l}\text { Individual } \\
\text { Subsidy } \\
\text { Benefit } \\
\left(6=5^{*} 2\right)\end{array}$ & $\begin{array}{l}\text { Benefit } \\
\text { Incidence } \\
\text { (7) }\end{array}$ & $N$ \\
\hline \multirow{6}{*}{$\begin{array}{l}\text { Primary: Sub- } \\
\text { centre, PHC, } \\
\text { UHC, \& others }^{\mathrm{a}}\end{array}$} & Poorest & 6189 & 0.319 & 12 & 161 & 150 & 48 & 32.29 & $\begin{array}{l}26 \\
241\end{array}$ \\
\hline & Poorer & 5323 & 0.274 & 15 & 161 & 147 & 40 & 27.23 & $\begin{array}{l}24 \\
845\end{array}$ \\
\hline & Middle & 3986 & 0.205 & 15 & 161 & 147 & 30 & 20.39 & $\begin{array}{l}22 \\
533\end{array}$ \\
\hline & Richer & 2612 & 0.134 & 15 & 161 & 147 & 20 & 13.36 & $\begin{array}{l}18 \\
983\end{array}$ \\
\hline & Richest & 1316 & 0.068 & 15 & 161 & 147 & 10 & 6.73 & $\begin{array}{l}13 \\
013\end{array}$ \\
\hline & & 19,426 & & & & & 148 & & $\begin{array}{l}105 \\
615\end{array}$ \\
\hline \multirow{6}{*}{$\begin{array}{l}\text { Secondary: } \\
\text { Government/ } \\
\text { Municipal, } \\
\text { Rural Hospital }\end{array}$} & Poorest & 20,052 & 0.233 & 15 & 161 & 147 & 34 & 23.63 & $\begin{array}{l}26 \\
241\end{array}$ \\
\hline & Poorer & 19,522 & 0.227 & 18 & 161 & 144 & 33 & 22.55 & $\begin{array}{l}24 \\
845\end{array}$ \\
\hline & Middle & 18,547 & 0.215 & 18 & 161 & 143 & 31 & 21.31 & $\begin{array}{l}22, \\
533\end{array}$ \\
\hline & Richer & 16,371 & 0.190 & 19 & 161 & 142 & 27 & 18.72 & $\begin{array}{l}18, \\
983\end{array}$ \\
\hline & Richest & 11,697 & 0.136 & 15 & 161 & 147 & 20 & 13.79 & $\begin{array}{l}13 \\
013\end{array}$ \\
\hline & & 86,189 & & & & & 144 & & $\begin{array}{l}105 \\
615\end{array}$ \\
\hline \multirow[t]{6}{*}{$\begin{array}{l}\text { Any public } \\
\text { health centre }\end{array}$} & Poorest & 26,241 & 0.248 & 15 & 161 & 147 & 36 & 25.10 & $\begin{array}{l}29 \\
729\end{array}$ \\
\hline & Poorer & 24,845 & 0.235 & 16 & 161 & 145 & 34 & 23.53 & $\begin{array}{l}29 \\
729\end{array}$ \\
\hline & Middle & 22,533 & 0.213 & 18 & 161 & 144 & 31 & 21.12 & $\begin{array}{l}29 \\
729\end{array}$ \\
\hline & Richer & 18,983 & 0.180 & 18 & 161 & 144 & 26 & 17.80 & $\begin{array}{l}29 \\
729\end{array}$ \\
\hline & Richest & 13,013 & 0.123 & 15 & 161 & 147 & 18 & 12.45 & $\begin{array}{l}29 \\
729\end{array}$ \\
\hline & & 105,615 & & & & & 145 & & $\begin{array}{l}148, \\
645\end{array}$ \\
\hline
\end{tabular}

${ }^{a}$ Others include additional Primary Healthcare Centre (PHC), Urban Health Post (UHP), Urban Family Welfare Centre (UFWC), Public sector health facility; 1 US $\$=$ INR 68.22

hospitals (Table 5) and any other public health centres (Table 6) for delivery care. The pattern of the distribution of the share of public subsidy in these facilities was similar to that in using PHCs, sub-centres, UHCs and other health facilities; however, the magnitude of the share of the benefit was lower. For instance, in the urban area, among women from the poorest wealth quintile, the share of the benefit of public subsidy was $27.82 \%$ among those who went to government/municipal hospitals, rural hospital while it was $28.46 \%$ among those availed services from any public health facility compared to $34.39 \%$ among those availed services from Subcentres, PHCs, UHCs, and others.

Figure 2 present the concentration curve (CC) for women who had institutional delivery at public and private health centres. The $\mathrm{CC}$ for women who went to public health centre is above the line of equality, indicating a pro-poor concentration of the of public health centre for delivery care services whereas $\mathrm{CC}$ is below the line of equality for women who went to private health centre suggesting a pro-rich concentration of the use of private health centres for delivery care services. 
Table 4 Utilization rate, out-of-pocket payment (OOP in US\$), and benefit incidence by place of residence, educational attainment, states and social group in Sub-centre, PHC, UHC on institutional delivery in India, 2015-16

\begin{tabular}{|c|c|c|c|c|c|c|c|c|c|}
\hline $\begin{array}{l}\text { Sub- } \\
\text { centre, } \\
\text { PHC, UHC, } \\
\text { others }^{\mathrm{a}}\end{array}$ & Quintile & $\begin{array}{l}\text { Number people } \\
\text { utilizing public } \\
\text { health service } \\
\text { (1) }\end{array}$ & $\begin{array}{l}\text { Utilization } \\
\text { Rate (2) }\end{array}$ & $\begin{array}{l}\text { Median OOP in } \\
\text { public health } \\
\text { service in US\$ } \\
\text { (3) }\end{array}$ & $\begin{array}{l}\text { Median cost of } \\
\text { service in private } \\
\text { health centre in } \\
\text { US\$ (4) }\end{array}$ & $\begin{array}{l}\text { Net subsidy at } \\
\text { public health } \\
\text { centre in US\$ } \\
(5=4-3)\end{array}$ & $\begin{array}{l}\text { Individual } \\
\text { Subsidy } \\
\text { Benefit } \\
\left(6=5^{*} 2\right)\end{array}$ & $\begin{array}{l}\text { Benefit } \\
\text { Incidence } \\
\text { (7) }\end{array}$ & $N$ \\
\hline \multirow[t]{6}{*}{ Urban } & Poorest & 853 & 0.343 & 14 & 191 & 177 & 61 & 34.39 & 6789 \\
\hline & Poorer & 622 & 0.250 & 15 & 191 & 176 & 44 & 24.93 & 5904 \\
\hline & Middle & 473 & 0.190 & 15 & 191 & 176 & 33 & 18.99 & 4818 \\
\hline & Richer & 303 & 0.122 & 16 & 191 & 175 & 21 & 12.10 & 3767 \\
\hline & Richest & 239 & 0.096 & 15 & 191 & 176 & 17 & 9.59 & 2794 \\
\hline & & 2490 & & & & & 176 & & $\begin{array}{l}24, \\
072\end{array}$ \\
\hline \multirow[t]{6}{*}{ Rural } & Poorest & 4567 & 0.270 & 12 & 147 & 135 & 36 & 27.34 & $\begin{array}{l}18 \\
905\end{array}$ \\
\hline & Poorer & 4223 & 0.249 & 15 & 147 & 132 & 33 & 24.73 & $\begin{array}{l}18 \\
214\end{array}$ \\
\hline & Middle & 3612 & 0.213 & 15 & 147 & 132 & 28 & 21.16 & $\begin{array}{l}17 \\
163\end{array}$ \\
\hline & Richer & 2904 & 0.171 & 15 & 147 & 132 & 23 & 17.01 & $\begin{array}{l}15 \\
421\end{array}$ \\
\hline & Richest & 1630 & 0.096 & 12 & 147 & 132 & 13 & 9.76 & $\begin{array}{l}11 \\
840\end{array}$ \\
\hline & & 16,936 & & & & & 133 & & $\begin{array}{l}81 \\
543\end{array}$ \\
\hline \multirow[t]{6}{*}{ LPS } & Poorest & 3850 & 0.284 & 12 & 142 & 130 & 37 & 28.67 & $\begin{array}{l}15, \\
983\end{array}$ \\
\hline & Poorer & 3579 & 0.264 & 13 & 142 & 129 & 34 & 26.35 & $\begin{array}{l}15 \\
565\end{array}$ \\
\hline & Middle & 2945 & 0.217 & 15 & 142 & 127 & 28 & 21.44 & $\begin{array}{l}14 \\
638\end{array}$ \\
\hline & Richer & 2089 & 0.154 & 12 & 142 & 130 & 20 & 15.56 & $\begin{array}{l}12, \\
929\end{array}$ \\
\hline & Richest & 1097 & 0.081 & 15 & 142 & 127 & 10 & 7.99 & 8767 \\
\hline & & 13,560 & & & & & 129 & & $\begin{array}{l}67 \\
882\end{array}$ \\
\hline \multirow[t]{6}{*}{ HPS } & Poorest & 2020 & 0.344 & 15 & 180 & 166 & 57 & 34.44 & 9693 \\
\hline & Poorer & 1585 & 0.270 & 15 & 180 & 166 & 45 & 27.02 & 8925 \\
\hline & Middle & 1174 & 0.200 & 15 & 180 & 166 & 33 & 20.01 & 7925 \\
\hline & Richer & 706 & 0.120 & 15 & 180 & 166 & 20 & 12.04 & 6478 \\
\hline & Richest & 381 & 0.065 & 15 & 180 & 166 & 11 & 6.50 & 4712 \\
\hline & & 5866 & & & & & 166 & & $\begin{array}{l}37 \\
733\end{array}$ \\
\hline \multirow{6}{*}{$\begin{array}{l}\text { Education } \\
\text { less than } \\
5 \text { year }\end{array}$} & Poorest & 1866 & 0.254 & 10 & 117 & 107 & 27 & 25.79 & 7615 \\
\hline & Poorer & 1719 & 0.234 & 13 & 117 & 104 & 24 & 23.11 & 7373 \\
\hline & Middle & 1619 & 0.221 & 12 & 117 & 105 & 23 & 22.06 & 7210 \\
\hline & Richer & 1276 & 0.174 & 13 & 117 & 104 & 18 & 17.15 & 6794 \\
\hline & Richest & 860 & 0.117 & 10 & 117 & 107 & 13 & 11.89 & 5815 \\
\hline & & 7340 & & & & & 105 & & $\begin{array}{l}34 \\
807\end{array}$ \\
\hline \multirow{2}{*}{$\begin{array}{l}\text { Education } \\
\text { more than } \\
5 \text { year }\end{array}$} & Poorest & 4162 & 0.344 & 13 & 176 & 163 & 56 & 34.64 & $\begin{array}{l}18 \\
360\end{array}$ \\
\hline & Poorer & 3271 & 0.271 & 15 & 176 & 161 & 44 & 26.98 & 16, \\
\hline
\end{tabular}


Table 4 Utilization rate, out-of-pocket payment (OOP in US\$), and benefit incidence by place of residence, educational attainment, states and social group in Sub-centre, PHC, UHC on institutional delivery in India, 2015-16 (Continued)

\begin{tabular}{|c|c|c|c|c|c|c|c|c|c|}
\hline $\begin{array}{l}\text { Sub- } \\
\text { centre, } \\
\text { PHC, UHC, } \\
\text { others }^{\mathrm{a}}\end{array}$ & Quintile & $\begin{array}{l}\text { Number people } \\
\text { utilizing public } \\
\text { health service } \\
\text { (1) }\end{array}$ & $\begin{array}{l}\text { Utilization } \\
\text { Rate (2) }\end{array}$ & $\begin{array}{l}\text { Median OOP in } \\
\text { public health } \\
\text { service in US\$ } \\
\text { (3) }\end{array}$ & $\begin{array}{l}\text { Median cost of } \\
\text { service in private } \\
\text { health centre in } \\
\text { US\$ (4) }\end{array}$ & $\begin{array}{l}\text { Net subsidy at } \\
\text { public health } \\
\text { centre in US\$ } \\
(5=4-3)\end{array}$ & $\begin{array}{l}\text { Individual } \\
\text { Subsidy } \\
\text { Benefit } \\
(6=5 * 2)\end{array}$ & $\begin{array}{l}\text { Benefit } \\
\text { Incidence } \\
(7)\end{array}$ & $\mathbf{N}$ \\
\hline & & & & & & & & & 854 \\
\hline & Middle & 2340 & 0.194 & 15 & 176 & 161 & 31 & 19.30 & $\begin{array}{l}14 \\
894\end{array}$ \\
\hline & Richer & 1489 & 0.123 & 15 & 176 & 161 & 20 & 12.28 & $\begin{array}{l}12 \\
117\end{array}$ \\
\hline & Richest & 824 & 0.068 & 15 & 176 & 161 & 11 & 6.80 & 8583 \\
\hline & & 12,086 & & & & & 162 & & $\begin{array}{l}70, \\
808\end{array}$ \\
\hline \multirow{6}{*}{$\begin{array}{l}\text { Schedule } \\
\text { caste / } \\
\text { Schedule } \\
\text { tribe }\end{array}$} & Poorest & 2324 & 0.278 & 10 & 147 & 136 & 38 & 28.10 & 9553 \\
\hline & Poorer & 2143 & 0.256 & 10 & 147 & 136 & 35 & 25.91 & 9286 \\
\hline & Middle & 1856 & 0.222 & 12 & 147 & 135 & 30 & 22.20 & 8904 \\
\hline & Richer & 1345 & 0.161 & 15 & 147 & 132 & 21 & 15.74 & 8237 \\
\hline & Richest & 688 & 0.082 & 15 & 147 & 132 & 11 & 8.05 & 6633 \\
\hline & & 8356 & & & & & 135 & & $\begin{array}{l}42 \\
613\end{array}$ \\
\hline \multirow{6}{*}{$\begin{array}{l}\text { Other } \\
\text { backward } \\
\text { class }\end{array}$} & Poorest & 2338 & 0.313 & 13 & 157 & 144 & 45 & 31.60 & $\begin{array}{l}10 \\
220\end{array}$ \\
\hline & Poorer & 1920 & 0.257 & 15 & 157 & 142 & 37 & 25.58 & 9508 \\
\hline & Middle & 1553 & 0.208 & 15 & 157 & 142 & 30 & 20.69 & 8462 \\
\hline & Richer & 1093 & 0.146 & 15 & 157 & 142 & 21 & 14.56 & 7117 \\
\hline & Richest & 562 & 0.075 & 13 & 1567 & 144 & 11 & 7.56 & 4859 \\
\hline & & 7466 & & & & & 143 & & $\begin{array}{l}40, \\
166\end{array}$ \\
\hline \multirow[t]{6}{*}{ Other } & Poorest & 1459 & 0.405 & 16 & 176 & 160 & 65 & 40.54 & 6247 \\
\hline & Poorer & 913 & 0.253 & 19 & 176 & 157 & 40 & 24.90 & 5615 \\
\hline & Middle & 626 & 0.174 & 15 & 176 & 161 & 28 & 17.55 & 4736 \\
\hline & Richer & 389 & 0.108 & 16 & 176 & 160 & 17 & 10.81 & 3642 \\
\hline & Richest & 217 & 0.060 & 12 & 176 & 164 & 10 & 6.20 & 2596 \\
\hline & & 3604 & & & & & 160 & & $\begin{array}{l}22 \\
836\end{array}$ \\
\hline
\end{tabular}

${ }^{a}$ Others include additional Primary Healthcare Centre (PHC), Urban Health Post (UHP), Urban Family Welfare Centre (UFWC), Public sector health facility; 1 US $\$=$ INR 68.22

Table 7 presents the concentration index for institutional delivery by place of residence, low/high performing states, educational attainment, household size, number of ANC visits and adverse birth outcome in India by use of services in public and private health centres. For women who went to public health centres, the CI value was negative for each of the selected variable, suggesting pro-a pro-poor utilization of services while was pro-rich for those who went to private health centres. The CI values was higher for women resided in urban areas and used a public health centre (CI: - 0.209) for delivery care compared to those who delivered in a private health centre (CI: -0.112$)$. Similarly, the CI was higher for mother who used private health centres for delivery services and were from rural area (CI: 0.281) compared to those form urban areas (CI: 0.217). The CI value of was higher for women resided in an HPS (0.177) compared to those to those resided in an LPS (0.113 ). On the contrary, in the case of private health centre the CI value was higher for women who resided in an LPS (0.318) compared to those who resided in an HPS (0.226). In the terms of education the CI value was higher in the case of women who used the public health care services had more than 5 years of education (0.177) compared to those who had having less than 5 years of education $(-0.063)$. Similarly, In the case of private health centre too, the $\mathrm{CI}$ value was higher among mothers having an education of more than 5 years 
Table 5 Utilization rate, out-of-pocket payment (OOP in US\$), and Benefit Incidence by place of residence, educational attainment, states and social group in Government/Municipal, Rural Hospital on institutional delivery in India, 2015-16

\begin{tabular}{|c|c|c|c|c|c|c|c|c|c|}
\hline $\begin{array}{l}\text { Government/ } \\
\text { Municipal, } \\
\text { Rural } \\
\text { Hospital }\end{array}$ & Quintile & $\begin{array}{l}\text { Number people } \\
\text { utilizing public } \\
\text { health service } \\
\text { (1) }\end{array}$ & $\begin{array}{l}\text { Utilization } \\
\text { Rate (2) }\end{array}$ & $\begin{array}{l}\text { Median OOP } \\
\text { in public } \\
\text { health service } \\
\text { in US\$ (3) }\end{array}$ & $\begin{array}{l}\text { Median cost of } \\
\text { service in private } \\
\text { health centre in } \\
\text { US\$ (4) }\end{array}$ & $\begin{array}{l}\text { Net subsidy at } \\
\text { public health } \\
\text { centre in US\$ } \\
(5=4-3)\end{array}$ & $\begin{array}{l}\text { Individual } \\
\text { Subsidy } \\
\text { Benefit } \\
\left(6=5^{*} 2\right)\end{array}$ & $\begin{array}{l}\text { Benefit } \\
\text { Incidence } \\
\text { (7) }\end{array}$ & $N$ \\
\hline \multirow[t]{6}{*}{ Urban } & Poorest & 5936 & 0.275 & 16 & 191 & 174 & 48 & 27.82 & 6789 \\
\hline & Poorer & 5282 & 0.245 & 19 & 191 & 172 & 42 & 24.34 & 5904 \\
\hline & Middle & 4345 & 0.201 & 22 & 191 & 169 & 34 & 19.68 & 4818 \\
\hline & Richer & 3464 & 0.161 & 18 & 191 & 173 & 28 & 16.10 & 3767 \\
\hline & Richest & 2555 & 0.118 & 15 & 191 & 176 & 21 & 12.07 & 2794 \\
\hline & & 21,582 & & & & & 172 & & $\begin{array}{l}24, \\
072\end{array}$ \\
\hline \multirow[t]{6}{*}{ Rural } & Poorest & 14,338 & 0.222 & 15 & 147 & 132 & 29 & 22.50 & $\begin{array}{l}18, \\
905\end{array}$ \\
\hline & Poorer & 13,991 & 0.217 & 16 & 147 & 130 & 28 & 21.71 & $\begin{array}{l}18 \\
214\end{array}$ \\
\hline & Middle & 13,551 & 0.210 & 18 & 147 & 129 & 27 & 20.79 & $\begin{array}{l}17 \\
163\end{array}$ \\
\hline & Richer & 12,517 & 0.194 & 19 & 147 & 128 & 25 & 18.99 & $\begin{array}{l}15 \\
421\end{array}$ \\
\hline & Richest & 10,210 & 0.158 & 15 & 147 & 132 & 21 & 16.01 & $\begin{array}{l}11 \\
840\end{array}$ \\
\hline & & 64,607 & & & & & 130 & & $\begin{array}{l}81 \\
543\end{array}$ \\
\hline \multirow[t]{6}{*}{ LPS } & Poorest & 12,133 & 0.223 & 15 & 142 & 128 & 28 & 22.34 & $\begin{array}{l}15, \\
983\end{array}$ \\
\hline & Poorer & 11,986 & 0.221 & 15 & 142 & 128 & 28 & 22.06 & $\begin{array}{l}15 \\
565\end{array}$ \\
\hline & Middle & 11,693 & 0.215 & 15 & 142 & 128 & 27 & 21.53 & $\begin{array}{l}14 \\
638\end{array}$ \\
\hline & Richer & 10,840 & 0.200 & 15 & 142 & 128 & 25 & 19.96 & $\begin{array}{l}12, \\
929\end{array}$ \\
\hline & Richest & 7670 & 0.141 & 15 & 142 & 128 & 18 & 14.12 & 8767 \\
\hline & & 54,322 & & & & & 128 & & $\begin{array}{l}67 \\
882\end{array}$ \\
\hline \multirow[t]{6}{*}{ HPS } & Poorest & 7673 & 0.241 & 25 & 180 & 155 & 37 & 23.79 & 9693 \\
\hline & Poorer & 7340 & 0.230 & 23 & 180 & 157 & 36 & 22.97 & 8925 \\
\hline & Middle & 6751 & 0.212 & 25 & 180 & 155 & 33 & 20.93 & 7925 \\
\hline & Richer & 5772 & 0.181 & 23 & 180 & 157 & 28 & 18.12 & 6478 \\
\hline & Richest & 4331 & 0.136 & 16 & 180 & 164 & 22 & 14.19 & 4712 \\
\hline & & 31,867 & & & & & 157 & & $\begin{array}{l}37 \\
733\end{array}$ \\
\hline \multirow{6}{*}{$\begin{array}{l}\text { Education } \\
\text { less than } 5 \\
\text { years }\end{array}$} & Poorest & 5749 & 0.209 & 15 & 117 & 103 & 21 & 20.93 & 7615 \\
\hline & Poorer & 5654 & 0.206 & 15 & 117 & 103 & 21 & 20.58 & 7373 \\
\hline & Middle & 5591 & 0.204 & 15 & 117 & 103 & 21 & 20.36 & 7210 \\
\hline & Richer & 5518 & 0.201 & 15 & 117 & 103 & 21 & 20.09 & 6794 \\
\hline & Richest & 4955 & 0.180 & 15 & 117 & 103 & 19 & 18.04 & 5815 \\
\hline & & 27,467 & & & & & 103 & & $\begin{array}{l}34 \\
807\end{array}$ \\
\hline \multirow{2}{*}{$\begin{array}{l}\text { Education } \\
\text { more than } 5 \\
\text { year }\end{array}$} & Poorest & 14,198 & 0.242 & 18 & 176 & 158 & 38 & 24.41 & $\begin{array}{l}18 \\
360\end{array}$ \\
\hline & Poorer & 13,583 & 0.231 & 21 & 176 & 155 & 36 & 22.92 & 16 \\
\hline
\end{tabular}


Table 5 Utilization rate, out-of-pocket payment (OOP in US\$), and Benefit Incidence by place of residence, educational attainment, states and social group in Government/Municipal, Rural Hospital on institutional delivery in India, 2015-16 (Continued)

\begin{tabular}{|c|c|c|c|c|c|c|c|c|c|}
\hline $\begin{array}{l}\text { Government/ } \\
\text { Municipal, } \\
\text { Rural } \\
\text { Hospital }\end{array}$ & Quintile & $\begin{array}{l}\text { Number people } \\
\text { utilizing public } \\
\text { health service } \\
\text { (1) }\end{array}$ & $\begin{array}{l}\text { Utilization } \\
\text { Rate (2) }\end{array}$ & $\begin{array}{l}\text { Median OOP } \\
\text { in public } \\
\text { health service } \\
\text { in US\$ (3) }\end{array}$ & $\begin{array}{l}\text { Median cost of } \\
\text { service in private } \\
\text { health centre in } \\
\text { US\$ (4) }\end{array}$ & $\begin{array}{l}\text { Net subsidy at } \\
\text { public health } \\
\text { centre in US\$ } \\
(5=4-3)\end{array}$ & $\begin{array}{l}\text { Individual } \\
\text { Subsidy } \\
\text { Benefit } \\
\left(6=5^{*} 2\right)\end{array}$ & $\begin{array}{l}\text { Benefit } \\
\text { Incidence } \\
(7)\end{array}$ & $\mathbf{N}$ \\
\hline & & & & & & & & & 854 \\
\hline & Middle & 12,554 & 0.214 & 22 & 176 & 154 & 33 & 20.98 & $\begin{array}{l}14 \\
894\end{array}$ \\
\hline & Richer & 10,628 & 0.181 & 19 & 176 & 157 & 28 & 18.10 & $\begin{array}{l}12 \\
117\end{array}$ \\
\hline & Richest & 7759 & 0.132 & 15 & 176 & 161 & 21 & 13.59 & 8583 \\
\hline & & 58,722 & & & & & 157 & & $\begin{array}{l}70, \\
808\end{array}$ \\
\hline \multirow{6}{*}{$\begin{array}{l}\text { Schedule } \\
\text { caste / } \\
\text { Schedule } \\
\text { tribe }\end{array}$} & Poorest & 7229 & 0.211 & 15 & 147 & 132 & 28 & 21.34 & 9553 \\
\hline & Poorer & 7143 & 0.209 & 15 & 147 & 132 & 28 & 21.09 & 9286 \\
\hline & Middle & 7048 & 0.206 & 18 & 147 & 128 & 26 & 20.23 & 8904 \\
\hline & Richer & 6892 & 0.201 & 18 & 147 & 129 & 26 & 19.89 & 8237 \\
\hline & Richest & 5945 & 0.174 & 15 & 147 & 131 & 23 & 17.45 & 6633 \\
\hline & & 34,257 & & & & & 130 & & $\begin{array}{l}42 \\
613\end{array}$ \\
\hline \multirow{6}{*}{$\begin{array}{l}\text { Other } \\
\text { backward } \\
\text { class }\end{array}$} & Poorest & 7882 & 0.241 & 15 & 157 & 142 & 34 & 24.25 & $\begin{array}{l}10 \\
220\end{array}$ \\
\hline & Poorer & 7588 & 0.232 & 15 & 157 & 142 & 33 & 23.58 & 9508 \\
\hline & Middle & 6909 & 0.211 & 16 & 157 & 141 & 30 & 21.04 & 8462 \\
\hline & Richer & 6024 & 0.184 & 18 & 157 & 139 & 26 & 18.15 & 7117 \\
\hline & Richest & 4297 & 0.131 & 15 & 157 & 142 & 19 & 13.22 & 4859 \\
\hline & & 32,700 & & & & & 141.3 & & $\begin{array}{l}40 \\
166\end{array}$ \\
\hline \multirow[t]{6}{*}{ Others } & Poorest & 4788 & 0.249 & 22 & 176 & 154 & 38 & 24.96 & 6247 \\
\hline & Poorer & 4702 & 0.244 & 26 & 176 & 150 & 37 & 23.92 & 5615 \\
\hline & Middle & 4110 & 0.214 & 23 & 176 & 152 & 33 & 21.26 & 4736 \\
\hline & Richer & 3253 & 0.169 & 23 & 176 & 153 & 26 & 16.91 & 3642 \\
\hline & Richest & 2379 & 0.124 & 15 & 176 & 161 & 20 & 12.96 & 2596 \\
\hline & & 19,232 & & & & & 153 & & $\begin{array}{l}22, \\
836\end{array}$ \\
\hline
\end{tabular}

(0.258) compared to those having less than 5 years of education (0.240). The CI value was higher for women who made 4 or more ANC visit (-0.184) used public health services compared to those who made less than 4 ANC visit (-0.107). Conversely, in the case of private health care centres the $\mathrm{CI}$ value was higher for women who made less than 4 or more ANC visits (0.298) utilizing private health centres compared to those having less than 4 ANC visits (0.257). The CI value was lower for women who had an adverse birth outcome $(-0.150)$ and used a public health facility compared to those who did not have adverse birth outcome $(-0.166)$. Similarly, in the case of private health facilities the $\mathrm{CI}$ value was lower for women who had an adverse birth outcome (0.280) compared to those who did not (0.302).
Figure 3 represents the concentration index for delivery care across the states of India by public and private health facilities. The CI value for mothers who used public health centres was -0.161 and negative for all the states. In contrast, the CI value for mothers who used private health centres was 0.296 and positive for all the states. A large variation in concentration index was observed across the states for both public and private health facilities. In the case of public health facilities, the CI value was the highest in Gujarat (CI: - 0.235) followed Kerala (CI: - 0.234) and Telangana (CI: 0.232) and the lowest in Jammu \& Kashmir (CI: - 0.047) followed by Sikkim (CI: - 0.066) and Himachal Pradesh $(-0.067)$. Across private health centres, the CI value was the highest in Tripura (CI: 0.585) followed by Madhya 
Table 6 Utilization rate, out-of-pocket payment (OOP in US\$), and Benefit incidence place of residence, educational attainment, states and social group on institutional delivery by wealth quintile in India, 2015-16

\begin{tabular}{|c|c|c|c|c|c|c|c|c|c|}
\hline Overall & Quintile & $\begin{array}{l}\text { Number people } \\
\text { utilizing public } \\
\text { health service } \\
\text { (1) }\end{array}$ & $\begin{array}{l}\text { Utilization } \\
\text { Rate (2) }\end{array}$ & $\begin{array}{l}\text { Median OOP in } \\
\text { public health } \\
\text { service in US\$ } \\
\text { (3) }\end{array}$ & $\begin{array}{l}\text { Median cost of } \\
\text { service in private } \\
\text { health centre in } \\
\text { US\$ (4) }\end{array}$ & $\begin{array}{l}\text { Net subsidy at } \\
\text { public health } \\
\text { centre in US\$ } \\
(5=4-3)\end{array}$ & $\begin{array}{l}\text { Individual } \\
\text { Subsidy } \\
\text { Benefit } \\
\left(6=5^{*} 2\right)\end{array}$ & $\begin{array}{l}\text { Benefit } \\
\text { Incidence } \\
\text { (7) }\end{array}$ & $N$ \\
\hline \multirow[t]{6}{*}{ Urban } & Poorest & 6789 & 0.282 & 16 & 191 & 175 & 49 & 28.46 & 8461 \\
\hline & Poorer & 5904 & 0.245 & 18 & 191 & 173 & 42 & 24.46 & 8460 \\
\hline & Middle & 4818 & 0.200 & 20 & 191 & 171 & 34 & 19.69 & 8460 \\
\hline & Richer & 3767 & 0.156 & 18 & 191 & 173 & 27 & 15.61 & 8460 \\
\hline & Richest & 2794 & 0.116 & 15 & 191 & 176 & 20 & 11.77 & 8460 \\
\hline & & 24,072 & & & & & 173 & & $\begin{array}{l}42, \\
301\end{array}$ \\
\hline \multirow[t]{6}{*}{ Rural } & Poorest & 18,905 & 0.232 & 15 & 147 & 132 & 31 & 23.38 & $\begin{array}{l}21 \\
269\end{array}$ \\
\hline & Poorer & 18,214 & 0.223 & 15 & 147 & 131 & 29 & 22.40 & $\begin{array}{l}21 \\
270\end{array}$ \\
\hline & Middle & 17,163 & 0.210 & 17 & 147 & 130 & 27 & 20.92 & $\begin{array}{l}21 \\
268\end{array}$ \\
\hline & Richer & 15,421 & 0.189 & 18 & 147 & 129 & 24 & 18.65 & $\begin{array}{l}21 \\
269\end{array}$ \\
\hline & Richest & 11,840 & 0.145 & 15 & 147 & 132 & 19 & 14.64 & $\begin{array}{l}21 \\
268\end{array}$ \\
\hline & & 81,543 & & & & & 131 & & $\begin{array}{l}106, \\
344\end{array}$ \\
\hline \multirow[t]{6}{*}{ LPS } & Poorest & 15,983 & 0.235 & 15 & 142 & 128 & 30 & 23.55 & $\begin{array}{l}17 \\
852\end{array}$ \\
\hline & Poorer & 15,565 & 0.229 & 15 & 142 & 128 & 29 & 22.93 & $\begin{array}{l}17 \\
852\end{array}$ \\
\hline & Middle & 14,638 & 0.216 & 15 & 142 & 128 & 27 & 21.56 & $\begin{array}{l}17 \\
853\end{array}$ \\
\hline & Richer & 12,929 & 0.190 & 15 & 142 & 128 & 24 & 19.05 & $\begin{array}{l}17 \\
851\end{array}$ \\
\hline & Richest & 8767 & 0.129 & 15 & 142 & 128 & 16 & 12.92 & $\begin{array}{l}17 \\
851\end{array}$ \\
\hline & & 67,882 & & & & & 128 & & $\begin{array}{l}89, \\
259\end{array}$ \\
\hline \multirow[t]{6}{*}{ HPS } & Poorest & 9693 & 0.257 & 22 & 180 & 158 & 41 & 25.59 & $\begin{array}{l}11 \\
878\end{array}$ \\
\hline & Poorer & 8925 & 0.237 & 22 & 180 & 158 & 37 & 23.57 & $\begin{array}{l}11 \\
877\end{array}$ \\
\hline & Middle & 7925 & 0.210 & 23 & 180 & 158 & 33 & 20.83 & $\begin{array}{l}11 \\
877\end{array}$ \\
\hline & Richer & 6478 & 0.172 & 22 & 180 & 158 & 27 & 17.11 & $\begin{array}{l}11 \\
877\end{array}$ \\
\hline & Richest & 4712 & 0.125 & 16 & 180 & 158 & 21 & 12.90 & $\begin{array}{l}11 \\
877\end{array}$ \\
\hline & & 37,733 & & & & & 159 & & $\begin{array}{l}59 \\
386\end{array}$ \\
\hline \multirow{5}{*}{$\begin{array}{l}\text { Education } \\
\text { less than } \\
5 \text { years }\end{array}$} & Poorest & 7615 & 0.219 & 14 & 117 & 103 & 23 & 22.0 & 8410 \\
\hline & Poorer & 7373 & 0.212 & 15 & 117 & 103 & 22 & 21.15 & 8411 \\
\hline & Middle & 7210 & 0.207 & 15 & 117 & 103 & 21 & 20.68 & 8408 \\
\hline & Richer & 6794 & 0.195 & 15 & 117 & 103 & 20 & 19.49 & 8410 \\
\hline & Richest & 5815 & 0.167 & 15 & 117 & 103 & 17 & 16.68 & 8409 \\
\hline
\end{tabular}


Table 6 Utilization rate, out-of-pocket payment (OOP in US\$), and Benefit incidence place of residence, educational attainment, states and social group on institutional delivery by wealth quintile in India, 2015-16 (Continued)

\begin{tabular}{|c|c|c|c|c|c|c|c|c|c|}
\hline Overall & Quintile & $\begin{array}{l}\text { Number people } \\
\text { utilizing public } \\
\text { health service } \\
\text { (1) }\end{array}$ & $\begin{array}{l}\text { Utilization } \\
\text { Rate (2) }\end{array}$ & $\begin{array}{l}\text { Median OOP in } \\
\text { public health } \\
\text { service in US\$ } \\
\text { (3) }\end{array}$ & $\begin{array}{l}\text { Median cost of } \\
\text { service in private } \\
\text { health centre in } \\
\text { US\$ (4) }\end{array}$ & $\begin{array}{l}\text { Net subsidy at } \\
\text { public health } \\
\text { centre in US\$ } \\
(5=4-3)\end{array}$ & $\begin{array}{l}\text { Individual } \\
\text { Subsidy } \\
\text { Benefit } \\
\left(6=5^{*} 2\right)\end{array}$ & $\begin{array}{l}\text { Benefit } \\
\text { Incidence } \\
\text { (7) }\end{array}$ & $\mathrm{N}$ \\
\hline & & 34,807 & & & & & 103 & & $\begin{array}{l}42, \\
048\end{array}$ \\
\hline \multirow{6}{*}{$\begin{array}{l}\text { Education } \\
\text { more than } \\
5 \text { years }\end{array}$} & Poorest & 18,360 & 0.259 & 16 & 176 & 160 & 41 & 26.18 & $\begin{array}{l}21 \\
320\end{array}$ \\
\hline & Poorer & 16,854 & 0.238 & 18 & 176 & 158 & 37 & 23.70 & $\begin{array}{l}21 \\
320\end{array}$ \\
\hline & Middle & 14,894 & 0.210 & 21 & 176 & 155 & 33 & 20.65 & $\begin{array}{l}21 \\
321\end{array}$ \\
\hline & Richer & 12,117 & 0.171 & 18 & 176 & 158 & 27 & 17.12 & $\begin{array}{l}21 \\
317\end{array}$ \\
\hline & Richest & 8583 & 0.121 & 15 & 176 & 161 & 20 & 12.35 & $\begin{array}{l}21 \\
319\end{array}$ \\
\hline & & 70,808 & & & & & 158 & & $\begin{array}{l}106, \\
597\end{array}$ \\
\hline \multirow{6}{*}{$\begin{array}{l}\text { Schedule } \\
\text { caste/ } \\
\text { Schedule }\end{array}$} & Poorest & 9553 & 0.224 & 13 & 147 & 133 & 30 & 22.72 & $\begin{array}{l}10, \\
417\end{array}$ \\
\hline & Poorer & 9286 & 0.218 & 15 & 147 & 132 & 29 & 21.84 & $\begin{array}{l}10 \\
417\end{array}$ \\
\hline & Middle & 8904 & 0.209 & 16 & 147 & 130 & 27 & 20.69 & $\begin{array}{l}10, \\
417\end{array}$ \\
\hline & Richer & 8237 & 0.193 & 16 & 147 & 130 & 25 & 19.16 & $\begin{array}{l}10 \\
417\end{array}$ \\
\hline & Richest & 6633 & 0.156 & 15 & 147 & 132 & 21 & 15.60 & $\begin{array}{l}10 \\
417\end{array}$ \\
\hline & & 42,613 & & & & & 132 & & $\begin{array}{l}52, \\
085\end{array}$ \\
\hline \multirow{6}{*}{$\begin{array}{l}\text { Other } \\
\text { backward } \\
\text { class }\end{array}$} & Poorest & 10,220 & 0.254 & 15 & 157 & 142 & 36 & 25.55 & $\begin{array}{l}12, \\
048\end{array}$ \\
\hline & Poorer & 9508 & 0.237 & 15 & 157 & 142 & 34 & 23.77 & $\begin{array}{l}12 \\
048\end{array}$ \\
\hline & Middle & 8462 & 0.211 & 16 & 157 & 141 & 30 & 20.93 & $\begin{array}{l}12, \\
048\end{array}$ \\
\hline & Richer & 7117 & 0.177 & 16 & 157 & 141 & 25 & 17.61 & $\begin{array}{l}12, \\
048\end{array}$ \\
\hline & Richest & 4859 & 0.121 & 15 & 157 & 142 & 17 & 12.15 & $\begin{array}{l}12 \\
048\end{array}$ \\
\hline & & 40,166 & & & & & 142 & & $\begin{array}{l}60 \\
240\end{array}$ \\
\hline \multirow[t]{6}{*}{ Others } & Poorest & 6247 & 0.274 & 22 & 176 & 154 & 42 & 27.29 & 7264 \\
\hline & Poorer & 5615 & 0.246 & 23 & 176 & 152 & 37 & 24.29 & 7264 \\
\hline & Middle & 4736 & 0.207 & 22 & 176 & 154 & 32 & 20.69 & 7264 \\
\hline & Richer & 3642 & 0.159 & 22 & 176 & 154 & 25 & 15.91 & 7264 \\
\hline & Richest & 2596 & 0.114 & 15 & 176 & 161 & 18 & 11.83 & 7264 \\
\hline & & 22,836 & & & & & 154 & & $\begin{array}{l}36 \\
320\end{array}$ \\
\hline
\end{tabular}

1 US $\$=$ INR 68.22

Pradesh (0.512) and Odisha (0.487) and the lowest in Telangana (CI: 0.114), followed by Gujarat (CI: 0.127) and Andhra Pradesh (CI: 0.148).

\section{Discussion}

Resource constraints are one of the major challenges faced by the public healthcare system in developing 


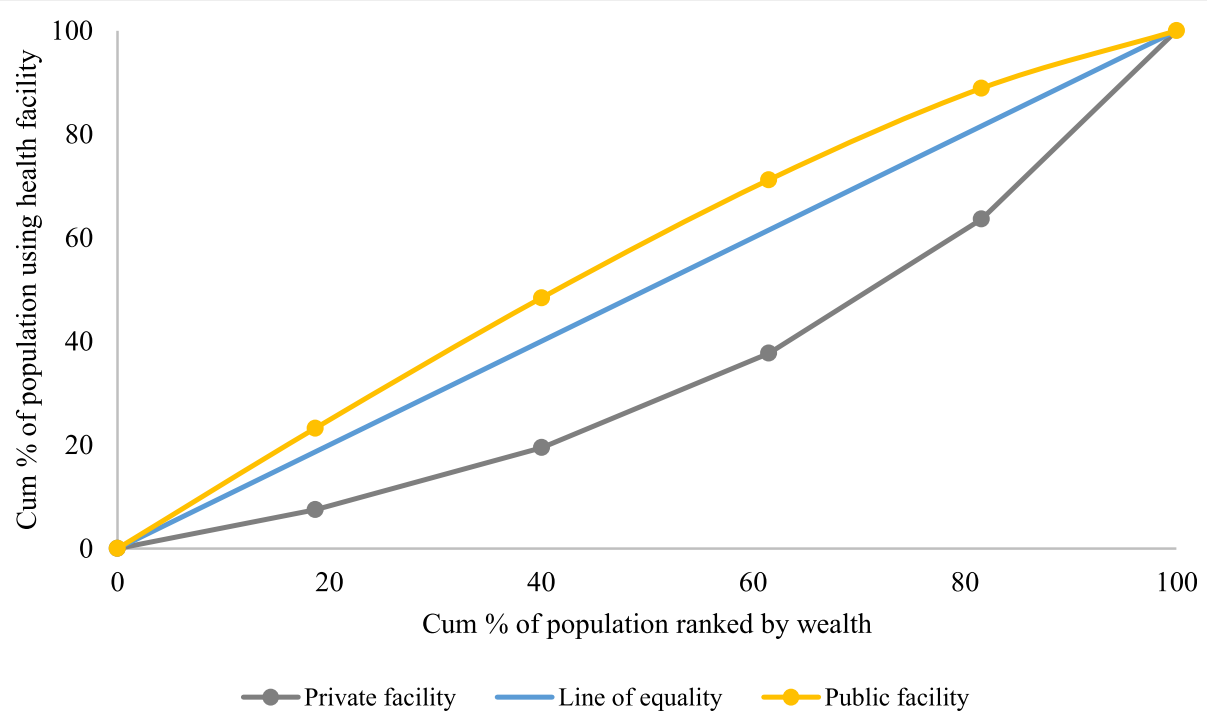

Fig. 2 Concentration curve for mothers using delivery services at public and private health facility in India, 2015-16

countries. Resources used for public health services have an opportunity cost, and in this context equity in health care is assumed to be significant. The NHM in India, the largest ever public health programmes worldwide has been operational for over 15 years. About half of the national health resources are invested in NHM, with the aim of achieving multiple objectives including increasing service coverage, reducing inequality in health care and health outcomes and reducing OOP payment and $\mathrm{CHS}$ specifically among the poor and the disadvantaged. The priorities of these schemes are usually to benefit the economically weaker section of the population, and studies attributed to increase in maternal care utilization and improvement in health outcome to the NHM [59-62].

Table 7 Concentration index for institutional delivery by selected covariates in India, 2015-16

\begin{tabular}{|c|c|c|c|c|}
\hline & \multicolumn{4}{|c|}{ Place of Delivery } \\
\hline & Public & 95\% Confidence Interval & Private & 95\% Confidence Interval \\
\hline \multicolumn{5}{|l|}{ Place of Residence } \\
\hline Rural & -0.112 & $(-0.115,-0.109)$ & 0.281 & $(0.273,0.290)$ \\
\hline Urban & -0.209 & $(-0.218,-0.200$ & 0.217 & $(0.207,0.226)$ \\
\hline \multicolumn{5}{|l|}{ State type } \\
\hline Low Performing States & -0.113 & $(-0.116,-0.110)$ & 0.318 & $(0.309,0.328)$ \\
\hline High Performing state & -0.177 & $(-0.184,-0.170)$ & 0.226 & $(0.217,0.235)$ \\
\hline \multicolumn{5}{|l|}{ Education } \\
\hline Less than 5 years & -0.063 & $(-0.067,-0.058)$ & 0.24 & $(0.222,0.258)$ \\
\hline 5 years and more & -0.177 & $(-0.182,-0.172)$ & 0.258 & $(0.251,0.265)$ \\
\hline \multicolumn{5}{|l|}{ Household Size } \\
\hline Up to 5 & -0.167 & $(-.0172,-0.162)$ & 0.307 & $(-.0299,0.315)$ \\
\hline 6 or more & -0.152 & $(-.0157,-0.147)$ & 0.277 & $(-.0267,0.287)$ \\
\hline \multicolumn{5}{|l|}{ Number of ANC visits } \\
\hline Less than 4 & -0.107 & $(-0.112,-0.102)$ & 0.298 & $(0.285,0.311)$ \\
\hline 4 and more & -0.184 & $(-0.189,-0.179)$ & 0.257 & $(0.249,0.265)$ \\
\hline \multicolumn{5}{|l|}{ Adverse Birth Outcome } \\
\hline No & -0.166 & $(-0.170,-0.162)$ & 0.302 & $(0.294,0.310)$ \\
\hline Yes & -0.150 & $(-0.156,-0.144)$ & 0.280 & $(0.269,0.291)$ \\
\hline Overall & -0.161 & $(-0.165,-0.158)$ & 0.296 & $(0.289,0.303)$ \\
\hline
\end{tabular}




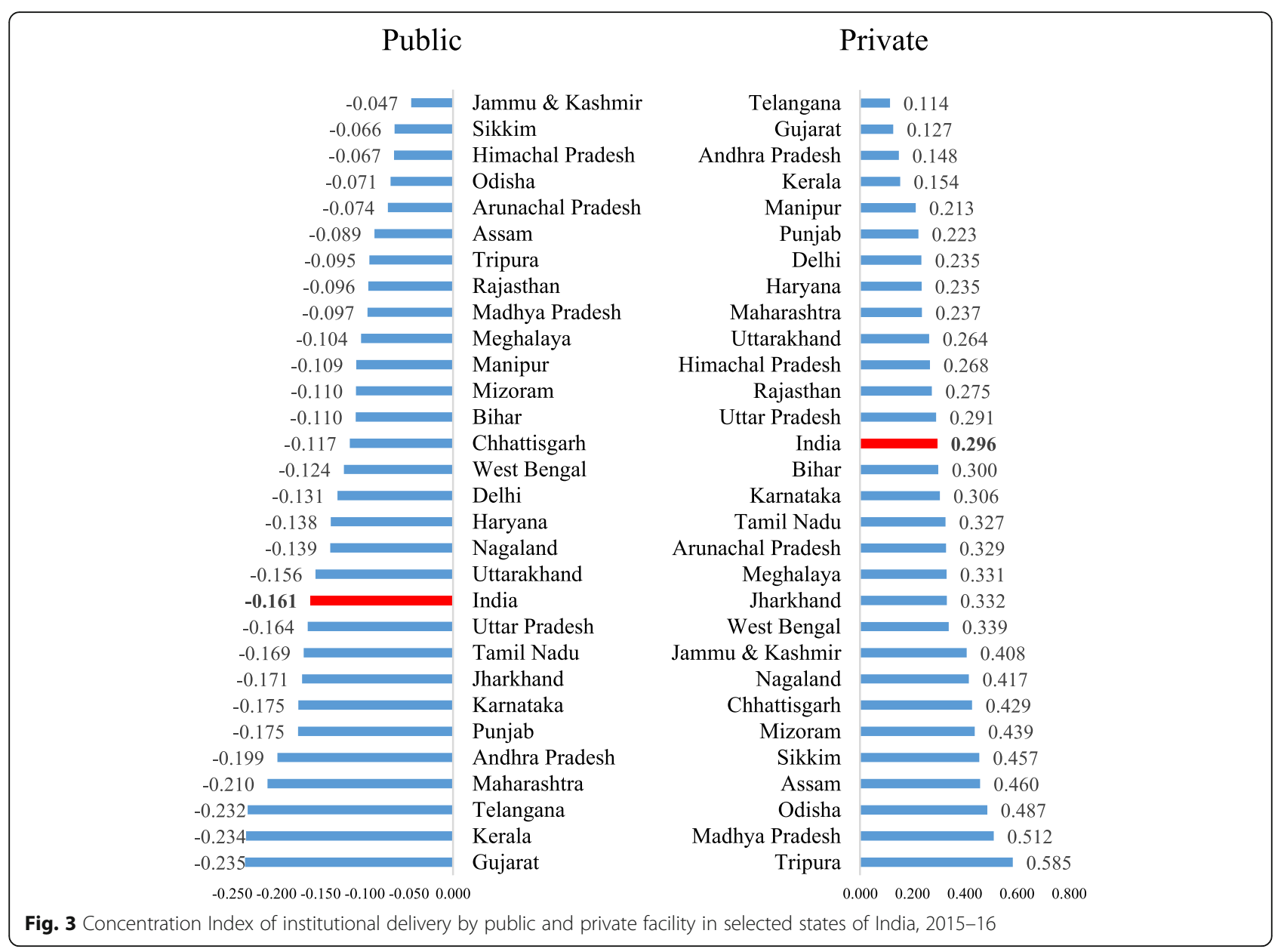

There are limited studies on the distributional aspect of public subsidy on health care utilisation in India. This study using the latest and largest-ever nationwide population-based survey data examine the distribution of public subsidy among mothers using primary and secondary public health centres considering institutional delivery as the case. The salient findings of the paper are as follows:

First, the utilization of delivery care in the public health centres is pro-poor. Mothers belonging to the poorest and poorer wealth quintile use more of the public health centre for delivery care while mothers from the richer and the richest wealth quintile use more of the private health centre for delivery care services. Second, the distribution of public subsidy for institutional delivery in both primary and secondary public health centre are pro-poor and the gradient is stronger in primary health centre compared to secondary health centres. About $32 \%$ of net subsidy were availed among women of the poorest wealth quintile and using primary health centres compared to $24 \%$ for women belonging to the poorest wealth quintile and who went to secondary health centres. Our findings regarding the subsidy being pro poor at the primary health centre is robust even through the use of alternative cost measures (quintile specific cost in private health centres). Third, the share of public subsidy is pro-poor in nature for each of the selected co-variates such as rural/urban, social class, and LPS/HPS across primary and secondary levels of care. However, within the same wealth quintile, we found a higher gradient in the use of services and the net benefit of subsidy among mother with higher educational attainment than those with lower educational attainment. Fourth, the concentration curve for mother using public health centres for delivery care was above the line of equality suggesting a pro-poor concentration of use of public health service on the other hand the curve was below the line of equality suggesting a pro-rich concentration of use of private health services. The CI value of -0.161 for public health centres and 0.296 for private health centres further confirms the concentration of use public health centres among the poor and private health centres among the rich. The state variation in the 
concentration index ware large for both public and private health services.

We provide some plausible explanations for our findings. The use of delivery care in public health centres is higher among the poorest and the poorer section of the population as public health centres are provided at free or very nominal cost and poor people has limited ability to pay for services. These findings may be due to implementation of JSY and other schemes under NHM that led to increase in utilization of maternal services $[30,60$, $61,63]$. The trend of pro-poor utilization of public health facilities in India is consistent with literatures. For example using the NSS 71st round data [30] showed with the help of concentration index (CI) that public service utilization at the national level is pro-poor for both inpatients and delivery care. The institutional delivery in private health centres is expensive and the services are mostly used by the richer and the richest wealth quintile. The OOP payment during delivery may be on the account of the complications in delivery care, caesarean delivery, cost of medicine, transportation costs and costs related to the and accompanying person, and has a strong and positive economic gradient. Mothers from the higher economic strata have a higher ability to pay for services and so they seek for better quality of care [64]. Our key findings regarding the net subsidy on institutional delivery being pro-poor in nature at primary and secondary health centre may be attributed to the provisioning of cash incentives and facilities under JSY and state-specific schemes. About two decades ago the hospitalization and outpatient services were pro-rich over the time, the tends have reversed [20,30]. Though our result about the pro-poor nature of the subsidy holds true for primary health centre even after using quintile specific costs, it does not hold true for secondary health centres. Although, the marginalized women should receive reimbursements and incentives from $\mathrm{NHM}$ and other maternal programmes, studies suggest that, these incentives are either insufficient or there are some other factors accounting for the inequality, such as, low education attainment, and low quality of the public health facilities in poorer areas [26, 65]. Regional variation in subsidy utilization can be another possible reason behind the unequal distribution of public subsidies. For instance, poor mothers from the LPS avail the benefit of subsidy which can be explained by the introduction of various maternal and child health programmes under NHM. Although inequality still exists, the level of inequality has reduced significantly across all groups in LPS [61, 65, 66]. Besides increasing facility based delivery, JSY has significantly increased contraceptive use, breastfeeding practice and post-natal check-up, all of which are closely associated with accessing public health facilities [60, 63]. The Ayushman Bharat scheme, that was launched by the Government of India in 2018 will provide further financial protection for the use of health services to 500 million people; accounting for $40 \%$ of the population of India in a phased manner. The scheme offers cashless payment for hospitalization to empanelled public and private hospitals covering an expenditure of US\$ 7329 (Rs.500,000) per family per year. It is the largest ever public sponsored insurance scheme worldwide and is operational in many states of India. As of October 25th, 2020, more than 12 scores people have already benefited from the scheme. Other such initiative include the Pradhan Mantri Matru Vandana Yojana (PMMVY) which offers a cash incentive of US\$ 73(Rs.5000) to pregnant and lactating mothers of age 19 years and above for their first live birth.

Our findings have the following implications. First, we suggest improving the physical infrastructure and service coverage in the public health centres, particularly the primary health centres. Our findings demonstrate a higher use of services and net subsidy at these centres by the poorest and the poorer sections of the population. But the primary health centres are equipped with limited services and infrastructure. A PHC constitutes an inpatient ward area with 4 to 6 beds, a labour room, and a minor operation theatre for a population of 20,000 to 30,000 based on the type of area [67] and is not equipped to conduct caesarean or complicated deliveries. The treatment availability of preventive services in PHCs is very minimal. It has been found that the utilization rate of public facilities from secondary level among the richer $40 \%$ of the population is more than that of primary level. This indicates that the richer section demand more public facilities at the secondary level. One potential reason behind this can be the better quality of care at the secondary level which attracts them to utilize the public health facilities. Besides, there may be certain impediment for the poor people to access secondary services. From the policy perspective, there is need for more equal and more efficient allocation of public spending at the primary level is required. At the secondary level, improving the quality of services and extending service coverage to non-communicable diseases is recommended. Addressing the impediments faced by the poor in availing quality services, particularly, caesarean and complicated delivery in public health centres may be considered. Implementing, these steps may help to reduce the high OOP payment and CHS among the poor and achieve equity in access to delivery care in India. Overall, there is need to improve the quality of care in public health centres to overcome geographical barriers in remote areas.

We outline the following limitations of the study. First, since we used self-reported data from the NFHS to estimate utilization pattern, OOP payments, and benefit 
incidence, there may have been be some recall bias. Besides, the indirect cost associated with institutional delivery was not covered in the survey. Second, we used the median cost of services in private health centres as a proxy for the cost of services in public health centres. An appropriate study on costing may provide more robust to bring out the actual scenario. Third, our results could not cover the impact of recent initiatives such Ayushmann Bharat, and the Pradhan Mantri Matru Vandana Yojana. As these were launched after the completion of the NFHS 4. Such analyses may be feasible with the release of the fifth round of the NFHS.

\section{Conclusion}

Public health spending should benefit the poor and the marginalized section of the society to achieve equity in health outcomes. At the national level, policies such as, the Rashtriya Swasthya Bima Yojana (RSBY), Ayushman Bharat, and the Pradhan Mantri Matru Vandana Yojana (PMMVY) have been providing protection against financial risks to the economically weaker section of the population. These policies are significant to change the very outline of health care access, utilization of services, and OOP expenditure. It is recommended to continue these programmes with greater monitoring surveillance to make them more pro-poor, so that the disadvantaged section of the population can receive the necessary support. Investing in the public health infrastructure and improving the quality of services in primary and secondary health centre is recommended.

\section{Supplementary Information}

The online version contains supplementary material available at https://doi. org/10.1186/s12939-020-01331-z.

Additional file 1. Utilization rate, out-of-pocket payment (OOP in US\$) and Benefit incidence on institutional delivery by wealth quintile and level of care in public health centres using quintile specific OOP in private health centres as proxy to cost of services in public health centres of India, 2015-16

\begin{abstract}
Abbreviations
NHM: National Health Mission; NFHS: National Family Health Survey; OOP: Out-of-Pocket Payment; UHC: Urban Health Centre; UHP: Urban Health Post; UFWC: Urban Family Welfare Centre; BIA: Benefit Incidence Analysis; $\mathrm{Cl}$ : Concentration Index; CC: Concentration Curve; CHS: Catastrophic Health Spending; MDG: Millennium Development Goals; SDG: Sustainable Development Goals; UHI: Universal Health index; PHC: Primary Health Centre; NCD: Non-Communicable Diseases; DHS: Demographic Health Survey; CEB: Census Enumeration Blocks; PPS: Probability Proportional to Size; UPHC: Urban Primary Health Centre; PCA: Principal Component Analysis; JSY: Janani Suraksha Yojana; LPS: Low Performing States; HPS: High Performing States; RSBY: Rashtriya Swasthya Bima Yojana
\end{abstract}

\section{Authors' contributions}

Conception and design of study: SKM; analysis and interpretation of data: SKM, SM and SS; drafting the manuscript: SKM, SS, SM, and RM; critical revision of the manuscript for important intellectual content: SKM, RM, SM, SS

\section{Funding}

Not applicable.

\section{Availability of data and materials}

The dataset used and analysed for the current study is available in DHS repository, [https://dhsprogram.com/data/dataset/India_Standard-DHS_2015. cfm?flag=0]

\section{Ethics approval and consent to participate}

As the analysis is based on secondary data available in the public domain, it needs no prior approval.

\section{Consent for publication}

This manuscript is an original work and has been done by the authors, SKM, RM, SM and SS who all are aware of its content and approve its submission. This manuscript has not been published elsewhere in part or in entirety, and is not under consideration by another journal. All authors gave their consent for publication in International Journal for Equity in Health.

\section{Competing interests}

The authors declare that they do not have any competing interest.

\section{Author details}

${ }^{1}$ Department of Fertility Studies, International Institute for Population Sciences, Mumbai, India. ${ }^{2}$ Research Scholar, International Institute for Population Sciences, Mumbai, India.

Received: 5 August 2020 Accepted: 20 November 2020

Published online: 09 December 2020

\section{References}

1. WHO. Global Spending on Health: A World in Transition 2019. Glob Rep. 2019;49 Available from: https://www.who.int/health_financing/documents/ health-expenditure-report-2019/en/

2. Mohanty SK, Kim R, Khan PK, Subramanian SV. Geographic variation in household and catastrophic health Spending in India: assessing the relative importance of villages, districts, and states, 2011-2012. Milbank Q. 2018; 96(1):167-206 https://doi.org/10.1111/1468-0009.12315.

3. Bor J, Cohen $\mathrm{GH}$, Galea S. Population health in an era of rising income inequality: USA, 1980-2015. Lancet. 2017;389(10077):1475-90 https://doi. org/10.1016/S0140-6736(17)30571-8.

4. Balarajan $Y$, Selvaraj S, Subramanian S. Health care and equity in India. Lancet. 2011;377(9764):505-15 Available from: https://linkinghub.elsevier. com/retrieve/pii/S0140673610618946.

5. WHO. Public spending on health: a closer look at global trends. 2018 Available from: http://apps.who.int/bookorders.

6. Fan $\mathrm{VY}$, Savedoff WD. The health financing transition: a conceptual framework and empirical evidence. Soc Sci Med. 2014;105:112-21 Available from: https://linkinghub.elsevier.com/retrieve/pii/S0277953614000392.

7. Wagstaff A, Flores G, Smitz M, Hsu J, Chepynoga K, Eozenou P. Progress on impoverishing health spending in 122 countries: a retrospective observational study. Lancet Glob Health. 2018;6(2):e180-92 Available from: https://linkinghub.elsevier.com/retrieve/pii/S2214109X17304862.

8. Pandey A, Ploubidis GB, Clarke L, Dandona L. Trends in catastrophic health expenditure in India: 1993 to 2014. Bull World Health Organ. 2018;96(1):1828 Available from: http://www.who.int/entity/bulletin/volumes/96/1/17-191 759.pdf.

9. WHO. WHO Global Health Expenditure Atlas. 2014. Available from: http:// www.who.int/about/licensing/copyright form/en/index.html.

10. Mohanty SK, Ladusingh L, Kastor A, Chauhan RK, Bloom DE. Pattern, growth and determinant of household health spending in India, 1993-2012. J Public Health. 2016;24(3):215-29 https://doi.org/10.1007/s10389-016-0712-0.

11. Karan A, Engelgau M, Mahal A. The household-level economic burden of heart disease in India. Trop Med Int Health. 2014;19(5):581-91.

12. Li $Y, W u ~ Q, X u L$, Legge $D$, Hao $Y, G a o ~ L$, et al. Factors affecting catastrophic health expenditure and impoverishment from medical expenses in China: policy implications of universal health insurance. Bull World Health Organ. 2012:90(9):664-71 Available from: http://www.who.int/bulletin/volumes/90/ 9/12-102178.pdf.

13. WHO. Tracking Universal Health Coverage: 2017 Global Monitoring Report. 2017 
14. Inter-Agency and Expert Group on Sustainable Development Goal Indicators. Final list of proposed Sustainable Development Goal indicators. In: Report of the Inter-Agency and Expert Group on Sustainable Development Goal Indicators; 2016.

15. UN. List of MDGs English: UN; 2015. 2015. Available from: www.un.org/ millenniumgoals.

16. World Health Organization (WHO). Primary Health Care on the Road to Universal Health Coverage, vol. 12; 2019. Available from: http://apps.who.int/ bookorders.

17. Williams I, Bryan S. Understanding the limited impact of economic evaluation in health care resource allocation: A conceptual framework Health Policy. 2007;80(1):135-43 Available from: https://inkinghub.elsevier. com/retrieve/pii/S0168851006000583.

18. Dieleman JL, Micah AE, Murray CJ. Global health spending and development assistance for health. JAMA. 2019;321(21):2073 https://doi.org/ 10.1001/jama.2019.3687.

19. Micah AE, Chen CS, Zlavog BS, Hashimi G, Chapin A, Dieleman JL. Trends and drivers of government health spending in sub-Saharan Africa, 19952015. BMJ Glob Health. 2019;4(1):e001159 https://doi.org/10.1136/bmjgh2018-001159.

20. Mahal A, Singh J, Afridi F, Lamba V, Gumber A, Selvaraju V. Who benefits from public health Spending in India. Natl Counc Appl Econ Res. 2001;81:175.

21. Onwujekwe O, Hanson K, Uzochukwu B. Are the poor differentially benefiting from provision of priority public health services? A benefit incidence analysis in Nigeria. Int J Equity Health. 2012;11(1):70.

22. Prinja S, Kanavos P, Kumar R. Health care inequities in North India: role of public sector in universalizing health care. Indian J Med Res. 2012;136(3): 421-31.

23. Bose M, Dutta A. Inequity in hospitalization care: a study on utilization of healthcare services in West Bengal. India. Int J Health Policy Manag. 2015; 4(1):29-38 https://doi.org/10.15171/ijhpm.2015.05.

24. Castro-leal F, Castro-leal F, Dayton J, Dayton J, Demery L, Demery L, et al. Public spending on health care in Africa. Bull World Health Organ. 2000;78: 66-74 Available from: https://www.ncbi.n/m.nih.gov/pmc/articles/PMC25606 01/pdf/10686734.pdf.

25. Chuma J, Maina T, Ataguba J. Does the distribution of health care benefits in Kenya meet the principles of universal coverage? BMC Public Health. 2012;12(1):20 Available from: http://www.biomedcentral.com/1471-245 $8 / 12 / 20$.

26. Asante A, Price J, Hayen A, Jan S, Wiseman V. Equity in health care financing in low- and middle-income countries: a systematic review of evidence from studies using benefit and financing incidence analyses. PLoS One. 2016; 11(4):e0152866 https://doi.org/10.1371/journal.pone.0152866.

27. Wagstaff A. Benefit-incidence analysis: are government health expenditures more pro-rich than we think? Health Econ. 2012;21(4):351-66 https://doi. org/10.1002/hec.1727.

28. O'Donnell O, van Doorslaer E, Rannan-Eliya RP, Somanathan A, Adhikari SR, Harbianto D, et al. The incidence of public spending on healthcare: comparative evidence from Asia. World Bank Econ Rev. 2007;21(1):93-123.

29. Peters DH, Garg A, Bloom G, Walker DG, Brieger WR, Hafizur RM. Poverty and access to health care in developing countries. Ann N Y Acad Sci. 2008; 1136:161-71.

30. Bowser D, Patenaude B, Bhawalkar M, Duran D, Berman P. Benefit incidence analysis in public health facilities in India: utilization and benefits at the national and state levels. Int J Equity Health. 2019;18(1):45 https://doi.org/10. 1186/s12939-019-0945-y.

31. Mclntyre D, Ataguba JE. How to do (or not to do) ... a benefit incidence analysis. Health Policy Plan. 2011;26(2):174-82 Available from: https:// academic.oup.com/heapol/article/26/2/174/592398.

32. Bose M, Dutta A. Health financing strategies to reduce out-of-pocket burden in India: a comparative study of three states. BMC Health Serv Res. 2018;18:830

33. Acharya D, Vaidyanathan G, Muraleedharan V. Do the poor benefit from public spending on healthcare in India? results from benefit (utilisation) incidence analysis in Tamil Nadu and Orissa. In: Strengthening evidencebase for sustainable health financing models in india view project; 2011. p. $1-38$.

34. International Institute for Population Sciences (IIPS), Macro I. National Family Health Survey (NFHS-3). Mumbai; 2007. Available from: http://rchiips.org/ NFHS/NFHS-3 Data/NOL-1/India_volume_I_corrected_17oct08.pdf.
35. WHO, UNICEF, UNFPA, World Bank Group, United Nations Population Division. Trends in Maternal Mortality: 1990 to 2017. Geneva: World Health Organization; 2019.

36. Brinda EM, Attermann J, Gerdtham UG, Enemark U. Socio-economic inequalities in health and health service use among older adults in India: results from the $\mathrm{WHO}$ study on global AGEing and adult health survey. Public Health. 2016;141:32-41 https://doi.org/10.1016/j.puhe.2016.08.005.

37. Baru R, Acharya A, Acharya S, Shiva Kumar AK, Nagaraj K. Inequities in access to health services in India: caste, class and region. Econ Polit Wkly. 2010;45(38):49-58.

38. Dilip TR. Utilization of inpatient care from private hospitals: trends emerging from Kerala. India. Health Policy Plan. 2010;25(5):437-46.

39. Kapur A, Baisnab P. Budget Brief 2017-18: National Health Mission (NHM), vol. 9: Jaypee Brothers Medical Publishers (P) Ltd; 2017. Available from: https://www.jaypeedigital.com/book/9789386322722/chapter/ch7.

40. International Institute for Population Sciences (IIPS) \& ICF. National Family Health Survey (NFHS-4), 2015-16. Mumbai: IIPS; 2017. http://rchiips.org/ NFHS/NFHS-4Reports/India.pdf.

41. Bhan N, Rao KD, Kachwaha S. Health inequalities research in India: a review of trends and themes in the literature since the 1990s. Int J Equity Health. 2016:15(1):1-8 https://doi.org/10.1186/s12939-016-0457-y.

42. Joe W. Distressed financing of household out-of-pocket health care payments in India: incidence and correlates. Health Policy Plan. 2015;30(6): 728-41.

43. Mohanty SK, Kastor A. Out-of-pocket expenditure and catastrophic health spending on maternal care in public and private health centres in India: a comparative study of pre and post national health mission period. Health Econ Rev. 2017:7(1):1-15.

44. Mohanty SK, Panda BK, Khan PK, Behera P. Out-of-pocket expenditure and correlates of caesarean births in public and private health centres in India. Soc Sci Med. 2019;224(November 2018):45-57 Available from: https:// linkinghub.elsevier.com/retrieve/pii/S0277953619300541.

45. Kastor A, Mohanty SK. Disease-specific out-of-pocket and catastrophic health expenditure on hospitalization in India: do Indian households face distress health financing? PLoS One. 2018;13(5):1-18.

46. Issac A, Chatterjee S, Srivastava A, Bhattacharyya S. Out of pocket expenditure to deliver at public health facilities in India: a cross sectional analysis. Reprod Health. 2016;13:99.

47. Ministry of Health and Family Welfare (MoHFW). National Health Accounts India 2004-05. New Delhi: MoHFW; 2009.

48. Ministry of Health and Family Welfare (MoHFW). National Health Accounts India 2013-14. New Delhi: MoHFW; 2016.

49. Dash A, Mohanty SK. Do poor people in the poorer states pay more for healthcare in India? BMC Public Health. 2019;19(1):1-17.

50. Hooda SK. Out-of-pocket payments for healthcare in India: who have affected the Most and why? J Health Manag. 2017;19(1):1-15

51. Mahal A. Policy implications of the distribution of public subsidies on health and education: the case of Karnataka. India. Comp Educ Rev. 2005;49(4): 552-74 https://doi.org/10.1086/454376.

52. Ngangbam S, Ladusingh L. Burden of disease and benefit incidence of public health expenditure in Northeast India. J Health Manag. 2015;17(3): 328-38 https://doi.org/10.1177/0972063415589226.

53. Bose $M$, Banerjee $S$. Equity in distribution of public subsidy for noncommunicable diseases among the elderly in India: an application of benefit incidence analysis. BMC Public Health. 2019:19(1):1-12.

54. Kiringai J, Mathenge N. Feminisation of Poverty in Kenya: Is Fiscal Policy the Panacea or Achilles Heel. In: PIA Network Session Paper presented during the 5th PEP Research Network General Meeting, (June 18-22); 2006. p. 1-19.

55. Gwatkin DR. Trends in health inequalities in developing countries. Lancet Glob Health. 2017;5(4):e371-2 https://doi.org/10.1016/S2214109X(17)30080-3.

56. Kakwani N, Wagstaff A, van Doorslaer E. Socioeconomic inequalities in health: measurement, computation, and statistical inference. J Econ. 1997; 77(1):87-103 https://linkinghub.elsevier.com/retrieve/pii/S030440769601 8076

57. Wagstaff $A$, Paci $P$, van Doorslaer E. On the measurement of inequalities in health. Soc Sci Med. 1991;33:545-57.

58. O'Donnell O, O'Neill S, Van Ourti T, Walsh B. Conindex: estimation of concentration indices. Stata J. 2016;16(1):112-38.

59. Mohanty SK, Kastor A. Out-of-pocket expenditure and catastrophic health spending on maternal care in public and private health centres in India: a 
comparative study of pre and post national health mission period. Health Econ Rev. 2017;7(1):31 https://doi.org/10.1186/s13561-017-0167-1.

60. Sen S, Chatterjee S, Khan PK, Mohanty SK. Unintended effects of Janani Suraksha Yojana on maternal care in India. SSM Popul Health. 2020;11: 100619 https://doi.org/10.1016/j.ssmph.2020.100619.

61. Ali B, Dhillon P, Mohanty SK. Inequalities in the utilization of maternal health care in the pre- and post-National Health Mission periods in India. J Biosoc Sci. 2019;52:198-212

62. Nair H, Panda R. Quality of maternal healthcare in India: Has the National Rural Health Mission made a difference? J Glob Health. 2011;1(1):79-86 Available from: http://www.ncbinlm.nih.gov/pubmed/23198105.

63. Lim SS, Dandona L, Hoisington JA, James SL, Hogan MC, Gakidou E. India's Janani Suraksha Yojana, a conditional cash transfer programme to increase births in health facilities: an impact evaluation. Lancet. 2010;375(9730):200923 https://doi.org/10.1016/S0140-6736(10)60744-1.

64. Mohanty SK, Srivastava A. Out-of-pocket expenditure on institutional delivery in India. Health Policy Plan. 2013;28(3):247-62 https://doi.org/10 1093/heapol/czs057.

65. Randive B, San Sebastian M, De Costa A, Lindholm L. Inequalities in institutional delivery uptake and maternal mortality reduction in the context of cash incentive program, Janani Suraksha Yojana: results from nine states in India. Soc Sci Med. 2014;123:1-6 https://doi.org/10.1016/.jsocscimed.2014. 10.042.

66. Vellakkal S, Gupta A, Khan Z, Stuckler D, Reeves A, Ebrahim S, et al. Has India's national rural health mission reduced inequities in maternal health services? A pre-post repeated cross-sectional study. Health Policy Plan. 2017; 32(1):79-90

67. Directorate General of Health Services Ministry of Health \& Family Welfare, India G of. Indian Public Health Standards (IPHS) Guidelines for Primary Health Centres Revised 2012. Indian Public Health Stand; 2012. p. 1-100 Available from: http://nhm.gov.in/images/pdf/guidelines/iphs/iphs-revisedguidlines-2012/primay-health-centres.pdf.

\section{Publisher's Note}

Springer Nature remains neutral with regard to jurisdictional claims in published maps and institutional affiliations.

Ready to submit your research? Choose BMC and benefit from:

- fast, convenient online submission

- thorough peer review by experienced researchers in your field

- rapid publication on acceptance

- support for research data, including large and complex data types

- gold Open Access which fosters wider collaboration and increased citations

- maximum visibility for your research: over $100 \mathrm{M}$ website views per year

At $\mathrm{BMC}$, research is always in progress.

Learn more biomedcentral.com/submissions 